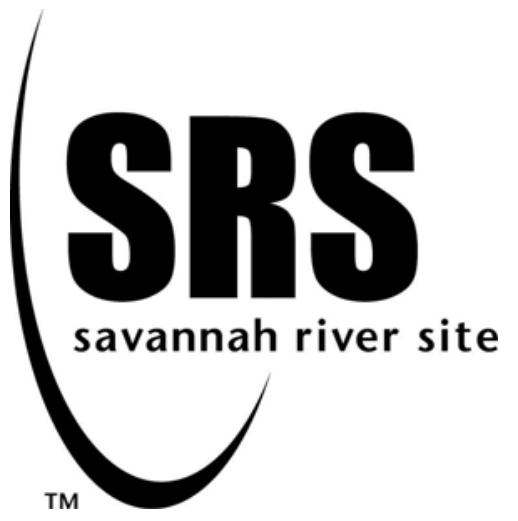

\title{
Pinch Weld Testing to Support Change in Manufacturing Oil at the KCP
}

\author{
Paul S. Korinko
}

David N. Maxwell

\section{Savannah River National Laboratory Washington Savannah River Company Savannah River Site Aiken, South Carolina}

This document was prepared in connection with work done under Contract No. DE-AC0996SR18500 with the U.S. Department of Energy. By acceptance of this document, the publisher and/or recipient acknowledges the U.S. Government's right to retain a nonexclusive, royalty-free license in and to any copyright covering this document, along with the right to reproduce and authorize others to reproduce all or part of the copyrighted material.

\section{WASHINGTON SAVANNAH RIVER COMPANY}

The WSRC Team: Washington Savannah River Company LLC • Bechtel Savannah River, Inc. • BNG America Savannah River Corporation • BWXT Savannah River Company • CH2 Savannah River Company 
This document was prepared in conjunction with work accomplished under Contract No. DE-AC09-96SR18500 with the U.S. Department of Energy.

This work was prepared under an agreement with and funded by the U.S. Government. Neither the U. S. Government or its employees, nor any of its contractors, subcontractors or their employees, makes any express or implied: 1 . warranty or assumes any legal liability for the accuracy, completeness, or for the use or results of such use of any information, product, or process disclosed; or 2 . representation that such use or results of such use would not infringe privately owned rights; or 3 . endorsement or recommendation of any specifically identified commercial product, process, or service. Any views and opinions of authors expressed in this work do not necessarily state or reflect those of the United States Government, or its contractors, or subcontractors. 


\section{Title: Pinch Weld Testing to Support Change in Manufacturing Oil at the KCP}

APPROVALS

P.S. Korinko, Author

Date

Materials Compatibility and Welding Technology

D.N. Maxwell, Authør

Date

Materials Compatibility and Welding Technology

E.A. Clark, Technical Reviewer

Date

Materials Compatibility and Welding Technology

W.L. West

Date

DP Weld Engineer

M.E. Dupont, Acting Manager

Date

Materials Compatibility and Welding Technology 
Table of Contents

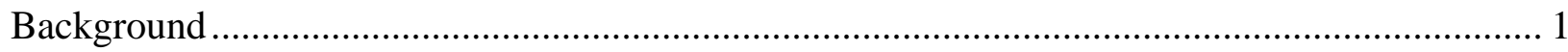

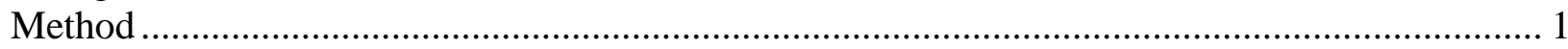

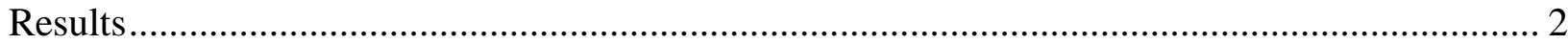

Type 304L stainless steel ............................................................................................ 2

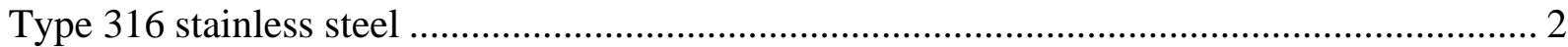

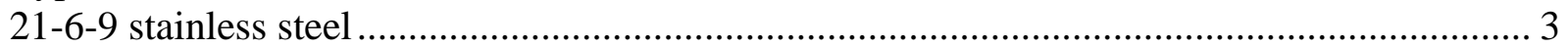

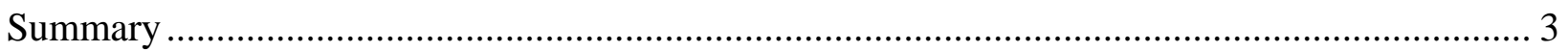

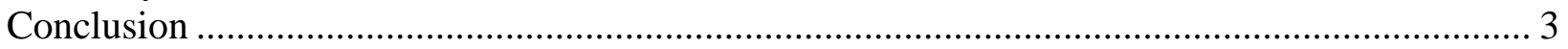

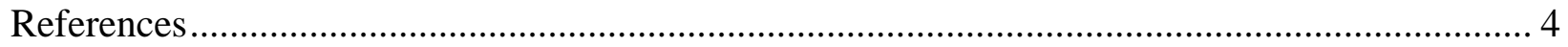

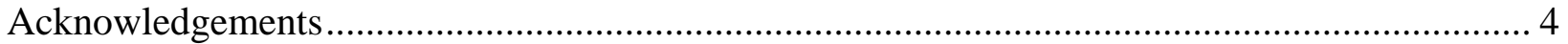

List of Figures

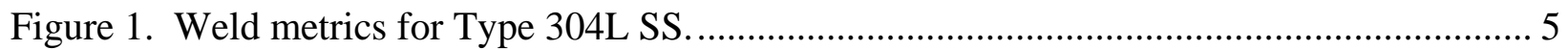

Figure 2. Typical micrographs for cold, nominal and hot welds in Type 304L SS PW................. 5

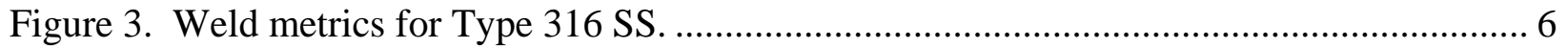

Figure 4. Typical micrographs for cold, nominal and hot welds in Type 316 SS PW. ................. 6

Figure 5. Weld Metrics for 21-6-9 SS ................................................................................. 7

Figure 6. Typical micrographs for cold, nominal and hot welds in 21-6-9 SS PW....................... 7

Figure 7. Comparison of weld closure length vs. weld energy for all three alloys. ....................... 8

List of Tables

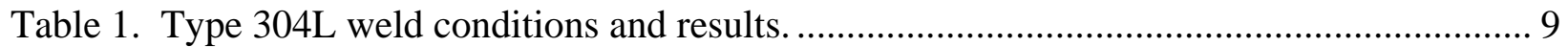

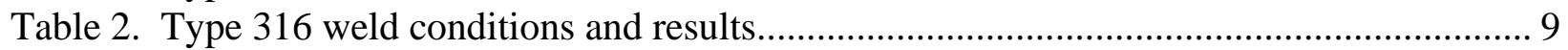

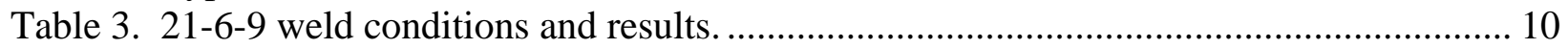

Table 4. Comparison of weld metrics and weld quality metrics for the two oils. ......................... 11

List of Appendices

Appendix A Fill stem manufacturing changes and pinch weld qualifications .............................. 12

Appendix B. Microstructures of 304L Stainless Steel pinch welds............................................. 14

Appendix C. Type 316 Stainless Steel pinch weld microstructures............................................. 24

Appendix D. 21-6-9 pinch weld microstructure ....................................................................... 34 
This Page Intentionally Left Blank 


\section{Background}

This task supports the change from an oil mixture termed 50:50 oil (an equal parts mixture of Milpro 634 and Pennex N47) to a new oil mixture (Castrol Illocut 334). This change was necessitated by a KCP vendor no longer supplying the Pennex N47 component of the 50-50. In order to continue production of machined parts, a detailed process was followed to ensure that high quality parts could be manufactured and that the cutting oil selected would provide acceptable human performance characteristics, e.g., skin irritability, smell, etc. A prime consideration in changing the oil was that no apparent change in the pinch weldability of the fill stems fabricated using the new oil and process parameters, if any, be observed.

A two part approach, as detailed in the plan shown in Appendix B, was used to qualify the effect of the process on pinch weld characteristics. In the first phase, ref. 1., the weld parameter window was defined using fill stems made from 304L, 21-6-9, and 316 stainless steel. These weld conditions were then subsequently used for the Castrol Illocut 334 machined fill stems. The results of this activity are reported in this document. A follow-on task of welding in the facility was requested by one of the design agencies and this will be completed and reported separately.

\section{Method}

Twelve fill stems of each material were manufactured using the improved KCP process with Castrol Illocut 334 oil. These stems were provided to SRS where they were examined using a forward looking borescope, pinch welded using 12 cycles and a 3/16" radius electrode in an LF-7 simulated reservoir with a standard LF-7 basket and confined pinch weld fixture at the conditions determined appropriate from the 50-50 oil stems, and then inspected using radiography, metrology, pressure testing, and metallography per the requirements in Ref. 2, a method that was used to originally qualify the 50-50 oil stems. The methods and inspection criteria detailed therein were used for several other studies, references 3-5. The pressure testing was done at pressures appropriate to the materials and pressure was held for 15 minutes per the high pressure laboratory procedure L9.4-8303. The samples were destructively analyzed by standard metallographic techniques. The samples were etched electrolytically with oxalic acid and examined at magnifications needed to determine the bond rating to the procedure, ref. 6 . Note that a different pinch weld inspector was used for this phase of the testing, consequently, there may be a slight change in the baseline. However, it was previously shown in a bond rating consistency study that there is an $85 \%$ correlation between inspectors. Furthermore, if there was any question regarding the bond rating interpretation, the Expert from the Defense Programs Metallography facility was consulted and was the final arbitrator for the bond rating. 


\section{Results}

\section{Type 304L stainless steel}

The type 304L stainless steel fill stems are welded between 3500 and $3900 \mathrm{~A}$ as was verified in phase 1 of this work, ref. 1 and the previous fill stem manufacturing and pinch weld processing task, ref. 3-5. The target current values were achieved by welding at nominal voltages of 345, 364, and 382V for 12 cycles, at a nominal force of 1250 lbs. The actual voltage, current, and weld force are listed in Table 1.

In addition to the process data, the weld quality metrics are also contained within Table 1 . It can be seen that the closure length exceeds the minimum requirement ( 0.100 inch), the thickness is within the acceptable range, and bond ratings all meet the requirement of class 1 or 2 . There is a mixture of solid state, partial liquation, and full nugget formation obtained for the weld conditions used in this task, this range of structure and weld output was observed previously (refs $3 \& 4)$.

Although weld energy is not one of the weld parameters monitored, it can sometime be useful in determining the cause for scatter of response variables in the weld data. The closure length, weld energy, and dynamic resistance as a function of weld voltage are plotted in Fig. 1. It can be seen that the weld energy and closure length increase with weld heat, as expected, whereas the dynamic resistance decreases with increasing voltage. The cause of the reduction in dynamic resistance is likely due to the relatively small change in weld voltage, $0.068 \mathrm{~V}$ compared to the larger change in weld current 460A over this range. Sample A098 exhibits a somewhat anomalous behavior with a nominal voltage of $345 \mathrm{~V}$, but a current that is about $5 \%$ higher than the other samples. This sample exhibited the onset of melting.

Metallographic examination was completed for each sample. Micrographs from typical cold, nominal, and hot welded stems are shown in Figure 2. The cold welds were typically solid state or exhibited a minor amount of incipient melting, the nominal welds exhibited from moderate melting to nugget formation, and the hot welds exhibited significant amounts of melting and extensive nugget formation. All of the type 304L stainless steel fill stem microstructures are included as Appendix C.

\section{Type 316 stainless steel}

The type 316 SS fill stems were welded at nominally 330, 343, and 363 volts or corresponding currents of 3300, 3500, and 3700A, as indicated in Table 2. This range is about $100 \mathrm{~A}$ cooler than the original set-up welds in an attempt to reduce the extent of melting developed. This range provides a more desirable weld range of about $30 \mathrm{~V}$. The weld closure length data and other weld quality parameters are shown in Fig. 3. As was the case for the Type 304L SS stems, the closure length and weld energy increase with increased weld voltage, while the dynamic resistance decreases with increased voltage. The closure length of sample B078 lies somewhat above the expected trend line. This sample was welded at a current that is about 100A higher 
than the other three stems and the longer closure, longer extrusion and high energy are all consistent with a higher weld current for this sample.

The samples were all examined metallographically and bond rated. Micrographs from a typical cold, nominal, and hot weld are shown in Fig. 4. These images indicate a solid state bond with evidence of a bond line, class 2, to a nugget, class 1 . These welds are consistent with the 50-50 oil manufactured stem welds. The weld micrographs are shown in Appendix D.

\section{1-6-9 stainless steel}

The 21-6-9 stems were welded at 347, 358, and $370 \mathrm{~V}$ or nominally 3500, 3600, and $3750 \mathrm{~A}$. The weld range is consistent with the set-up welds that exhibited bond ratings of 1 to 3, ref. 2 . The weld quality metrics are shown in Fig. 5 and as expected, there is an increase in weld closure length with increased voltage, an increase in weld energy, and a reduction in dynamic resistance.

The typical microstructures are shown in Fig. 6, and all of weld micrographs are contained in Appendix E. The 21-6-9 welds exhibit some solid state welds, but the majority are nuggets. The welds ranged from class 2 to class 1 bonds.

\section{Summary}

A proposed change in cutting oil was precipitated by a future lack of supply of one of the constituents of the currently used 50-50 oil. A series of tests including human factor, machining use, and drilling capability was conducted at the KCP. The final acceptance of the processing change is validation that no adverse effects are observed during pinch welding. To affect the change, a set of ten test stems of each material was welded. The welds were inspected using common testing methods including dimensional, radiography, pressure testing, and metallography with bond rating. The three materials were welded at conditions internally consistent for the alloy. The energy of welding and the resultant weld closure for the three alloys are shown in Fig. 7. This graph shows evidence of a non-linear relationship with a maximum closure length that approaches 0.180 inch. This "limit" has been observed previously for welds made using a 3/32 inch radius electrode and was attributed to geometric constraints of the fixturing and weld electrodes.

Table 4 comprises a direct correlation between the 50-50 oil stems and the Castrol Illocut 334 . The weld data are arranged to show that the weld conditions for 50-50 produce similar weld output for the Castrol.

\section{Conclusion}

There is no observable difference in the pinch weldability of test fill stems machined with 50-50 and Castrol Illocut 334. This oil does not appear to have any effect on the pinch weld characteristics and, based on this work, there are no outstanding testing issues that need to be addressed prior to recommending this oil for acceptance to the design agencies. 


\section{References}

1. SRNL-MST-2007-00194, "Fill Stem Manufacturing Changes and Pinch Weld Qualifications”, PS Korinko \& DN Maxwell, Dec. 2007.

2. WSRC-RP-2005-01589, "Pinch Weld Technical Specification for Screening Design of Experiments (DOEx)”, P. Korinko, May 2005.

3. KCP-613-8133, “Nuclear Weapons Complex Screening Experiment to Identify Variables Critical to Stem Closure Welds”, K. Arnold (KCP) \& P. Korinko, May 2006.

4. WSRC-STI-2006-00158, “Optimization Study for Fill Stem Manufacturing and Pinch Weld Processing”, P. Korinko \& K Arnold (KCP), Sept. 2006.

5. WSRC-STI-2006-00158, "Validation Study for Fill Stem Manufacturing and Pinch Weld Processing”, P. Korinko \& K Arnold (KCP), Aug. 2006.

6. SOP MTF-4.15, Metallurgical Evaluation of Reclamation Welds, August 1997.

\section{Acknowledgements}

Numerous people assisted in this task to make it successful. T. Curtis and L. Thacker provided metallurgical support and bond rating inspection. G. Crowe and W. Good and others in the high pressure lab supported the pressurization testing. B. West provided technical review and liaison with the DP radiography staff. The DP Radiography staff provided rapid response for examination and inspection. N. Miller provided material and data transport. C. Kestin consulted on the bond rating and metallographic sample examination. Special thanks to DP Management for providing financial support for us to complete this task. 


\section{Type 304L Weld Metrics}

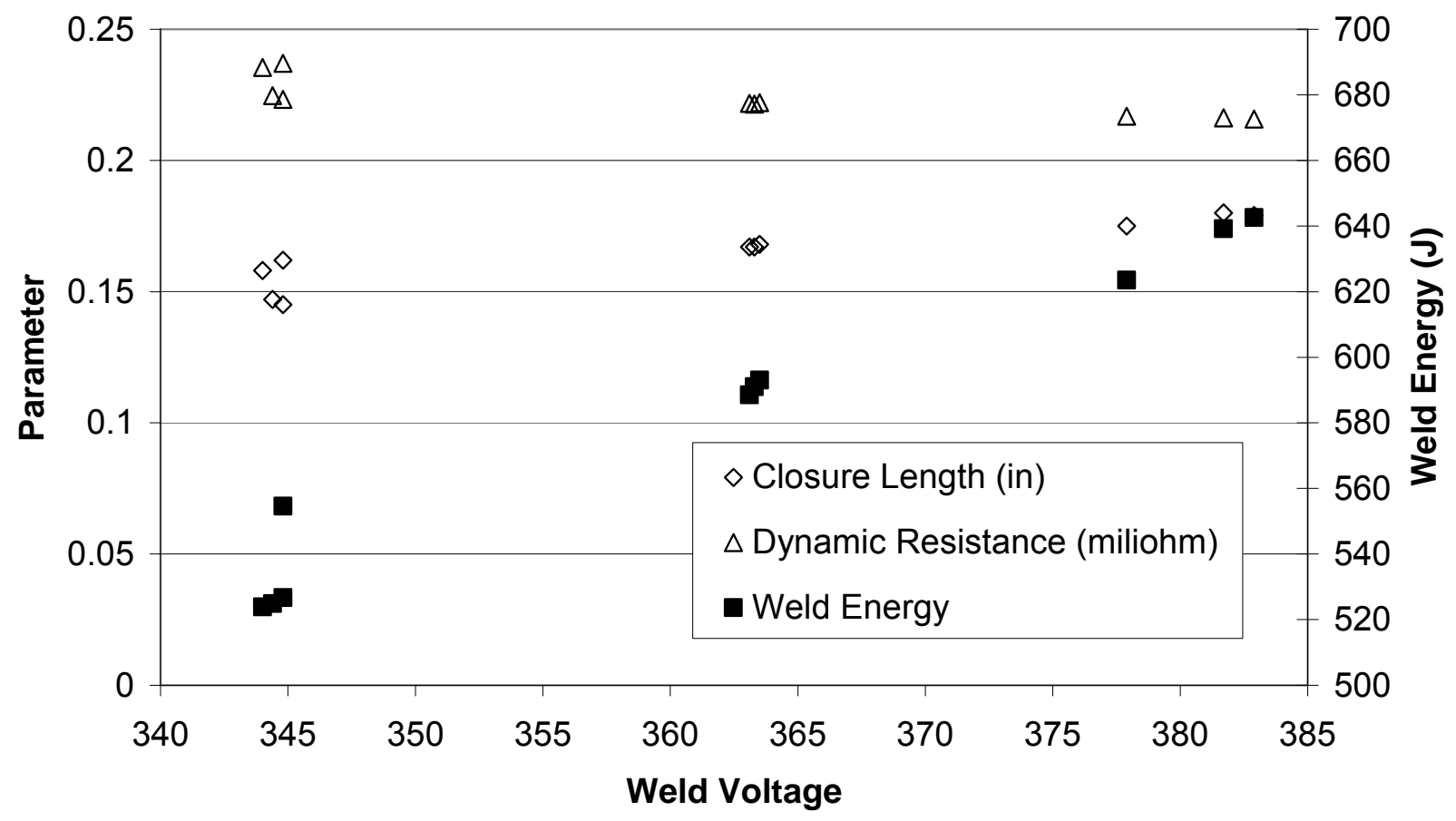

Figure 1. Weld metrics for Type 304L SS.

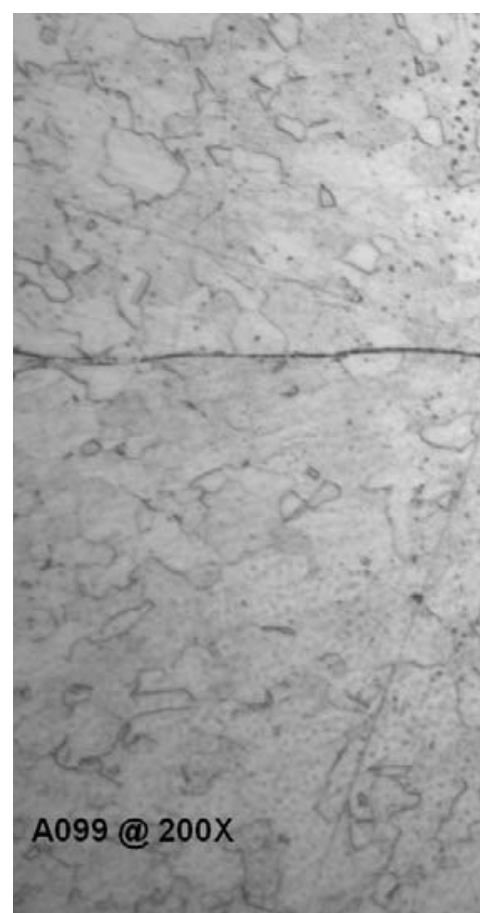

Cold

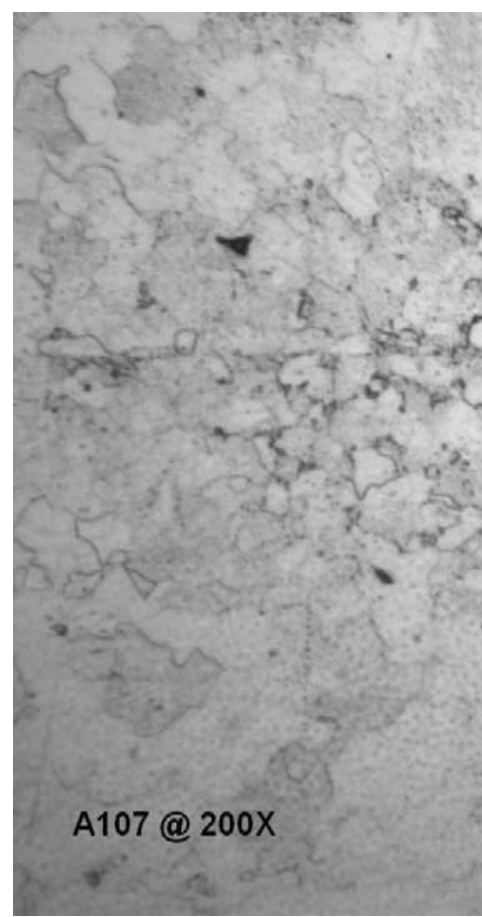

Nominal

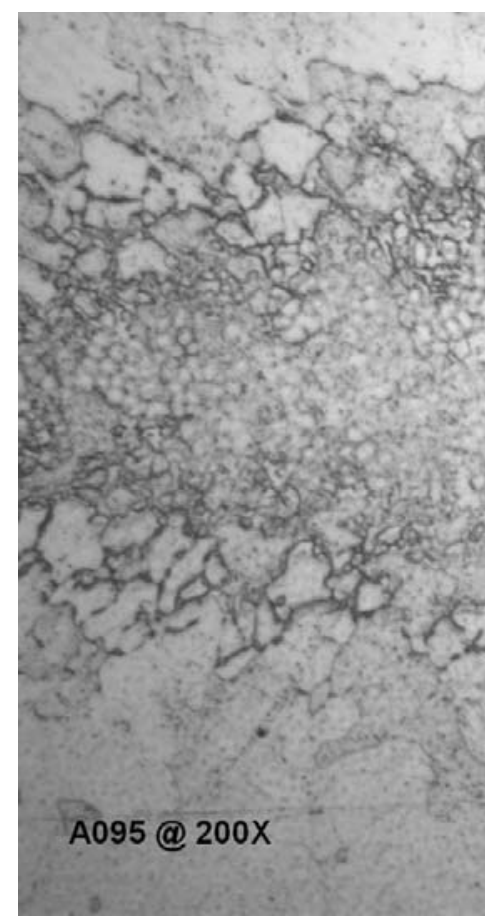

Hot

Figure 2. Typical micrographs for cold, nominal and hot welds in Type 304L SS PW. 


\section{Type 316 Weld Metrics}

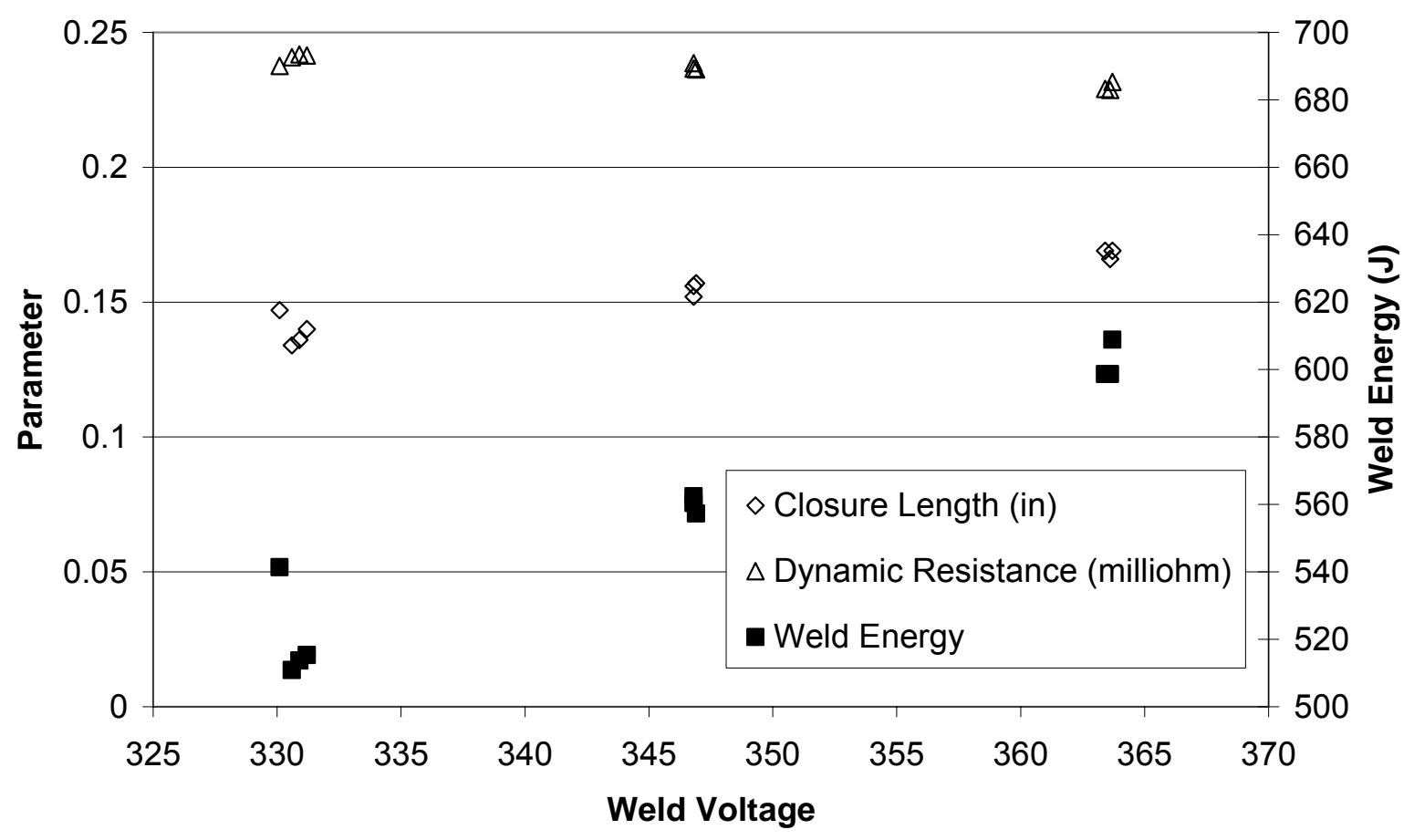

Figure 3. Weld metrics for Type 316 SS.

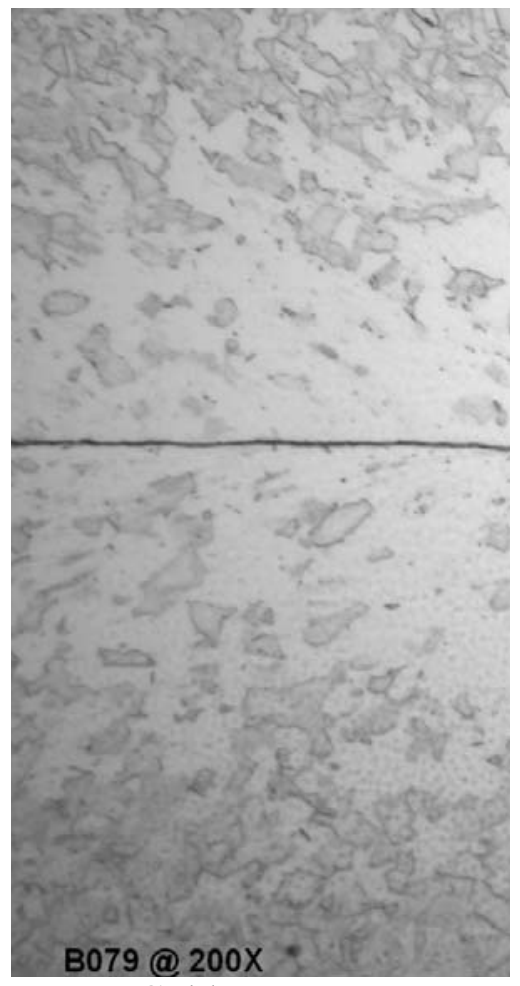

Cold

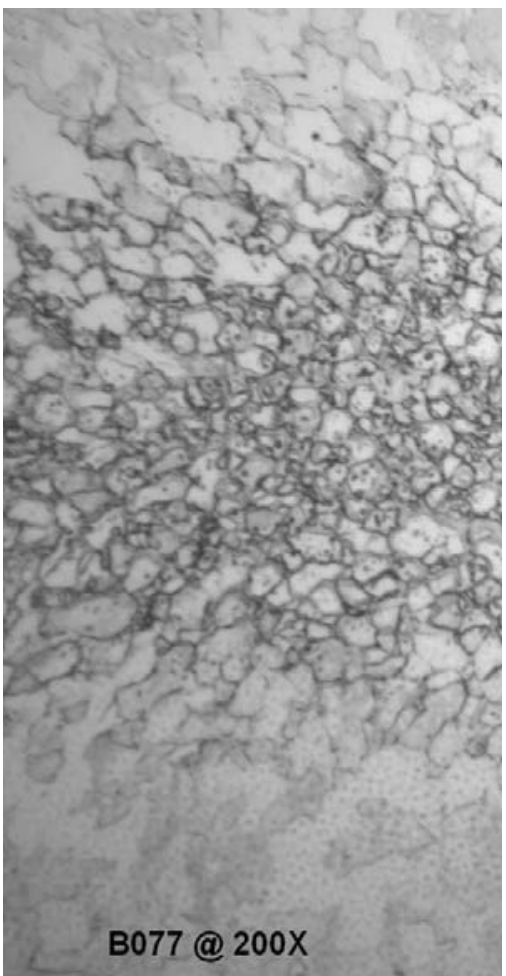

Nominal

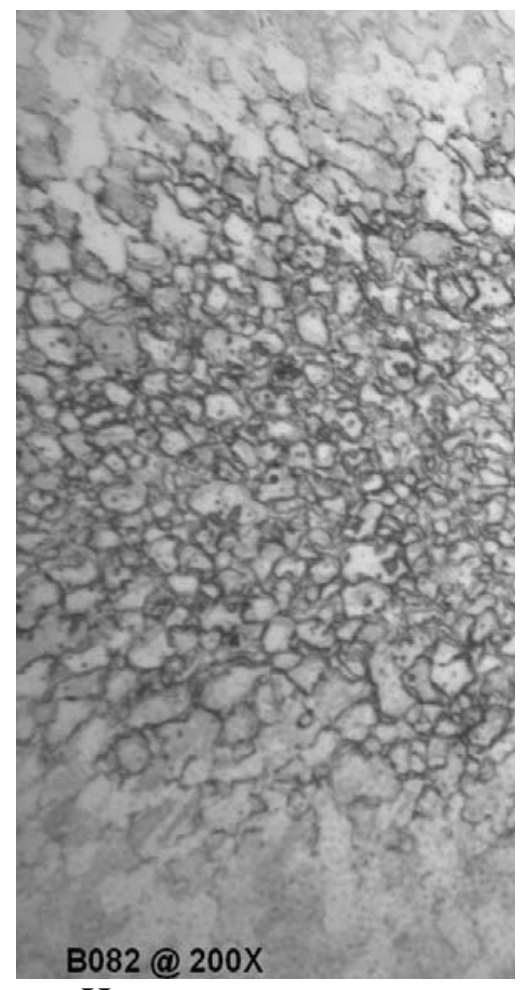

Hot

Figure 4. Typical micrographs for cold, nominal and hot welds in Type 316 SS PW. 


\section{Type 21-6-9 Weld Metrics}

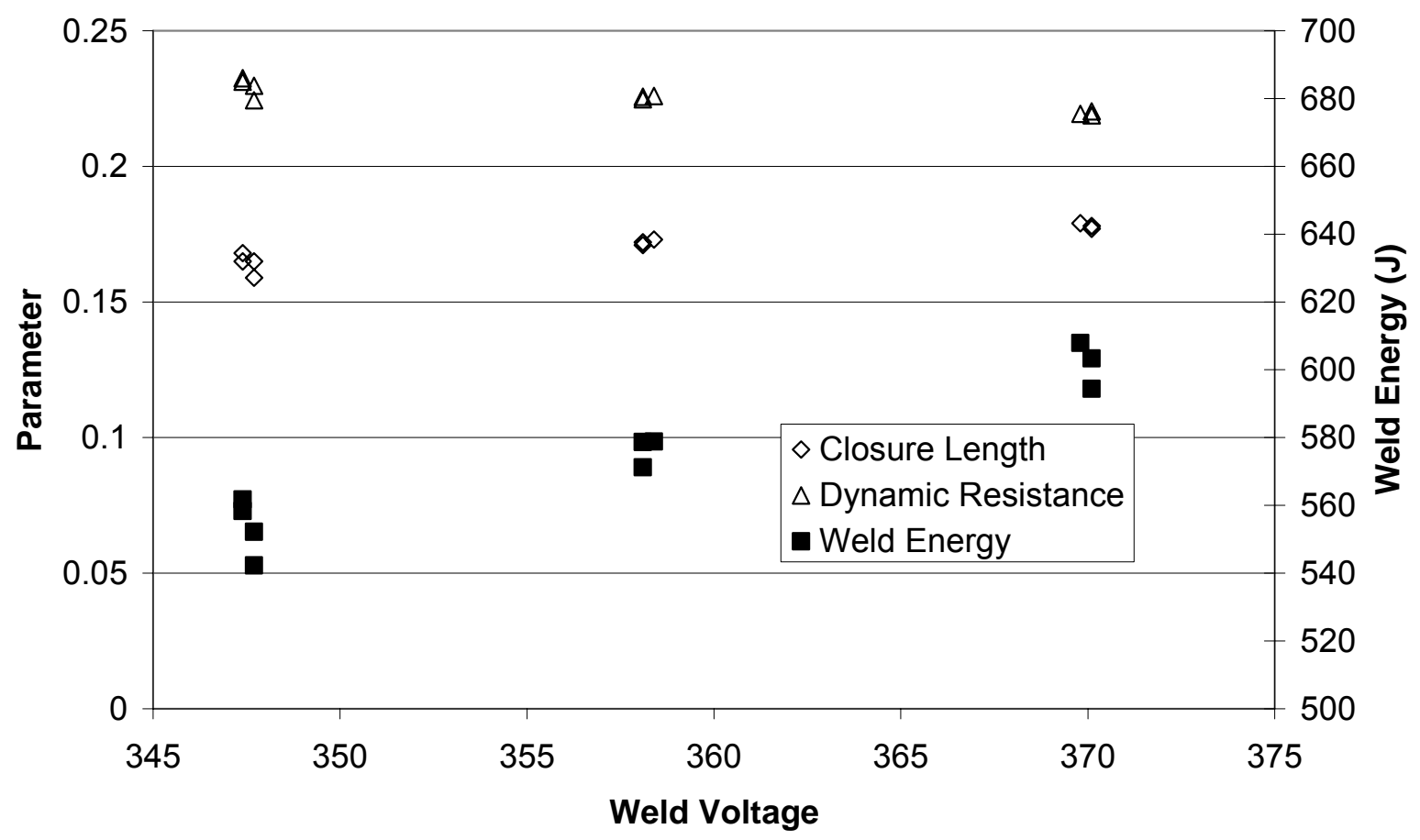

Figure 5. Weld Metrics for 21-6-9 SS

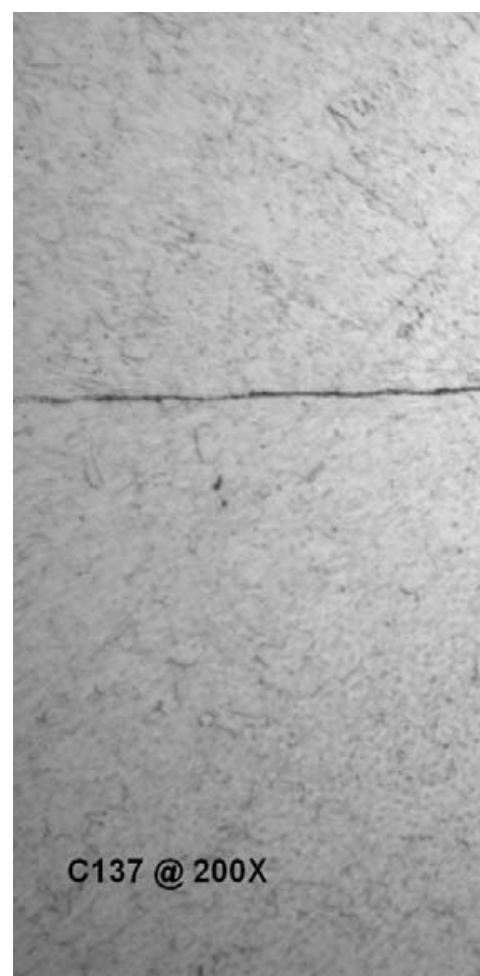

Cold

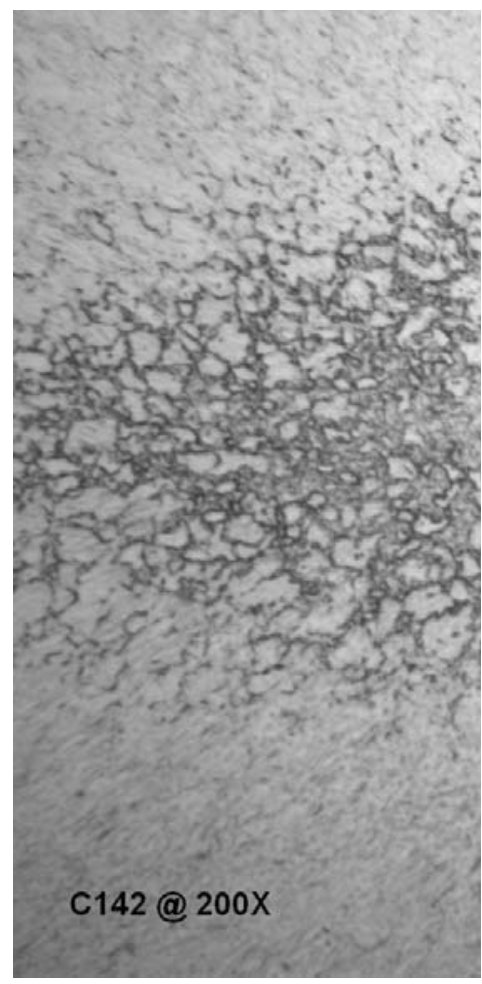

Nominal

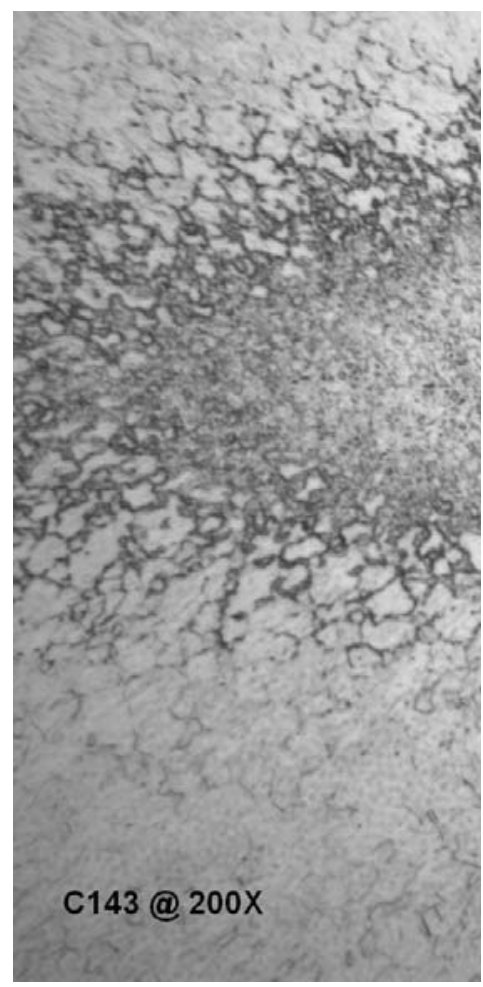

Hot

Figure 6. Typical micrographs for cold, nominal and hot welds in 21-6-9 SS PW. 
Comparison of weld energy to closure length for the three alloys

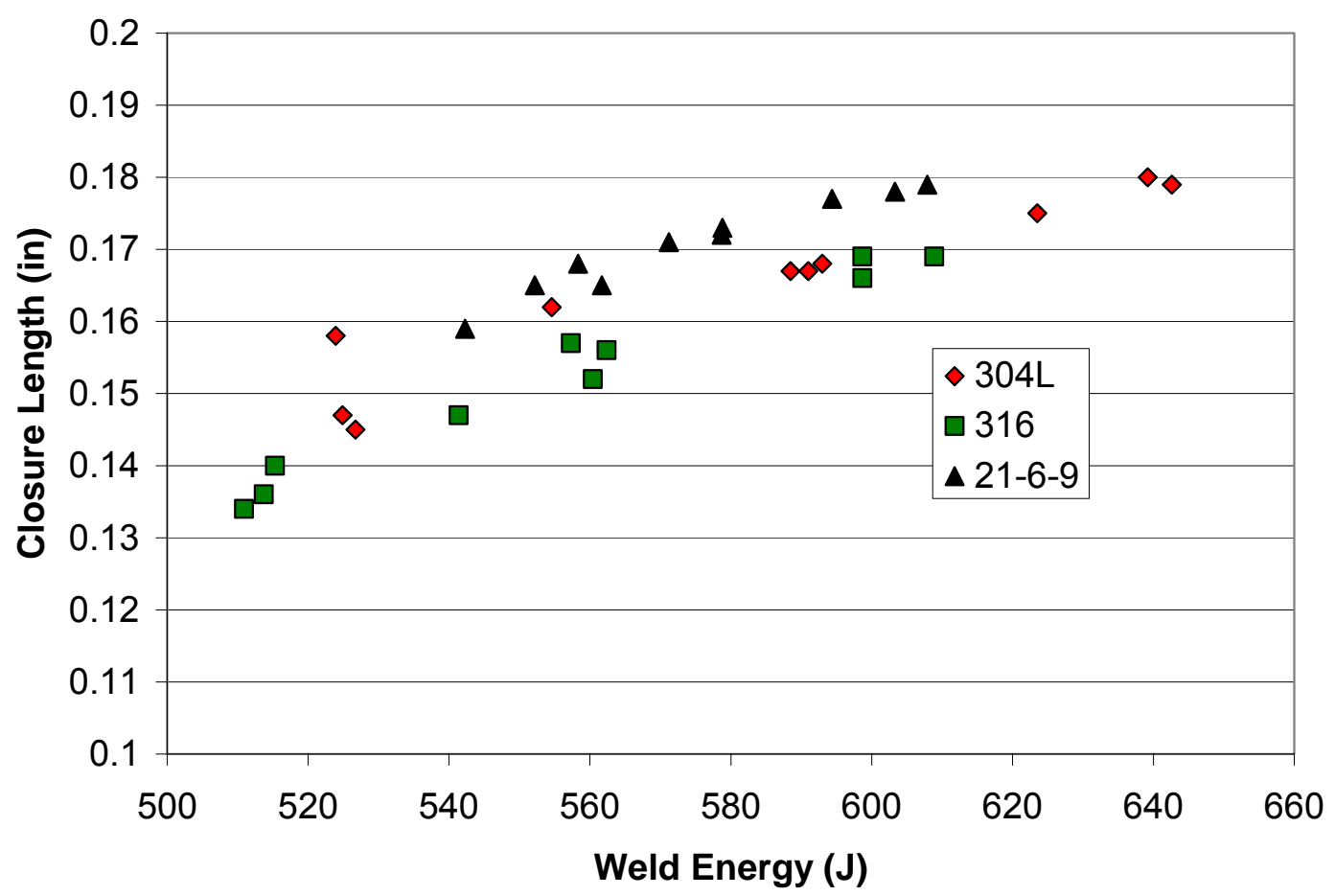

Figure 7. Comparison of weld closure length vs. weld energy for all three alloys. 
Table 1. Type 304L weld conditions and results.

\begin{tabular}{|c|c|c|c|c|c|c|c|c|c|c|c|c|c|c|}
\hline ID & $\begin{array}{l}\text { Volt } \\
\text { (V) }\end{array}$ & $\begin{array}{l}\text { Force } \\
\text { (Ibs) }\end{array}$ & $\begin{array}{l}\text { Press. } \\
\text { (psi) }\end{array}$ & $\begin{array}{l}\text { Stat. } \\
\text { Res. } \\
(\mathrm{m} \Omega) \\
\end{array}$ & $\begin{array}{l}\text { Dyn. } \\
\text { Res. } \\
(\mathrm{m} \Omega) \\
\end{array}$ & $\begin{array}{l}\text { Weld } \\
\text { Current } \\
\text { (A) }\end{array}$ & $\begin{array}{l}\text { Weld } \\
\text { Energy } \\
(\mathrm{J})\end{array}$ & $\begin{array}{l}\text { Weld } \\
\text { Volt } \\
\text { (V) } \\
\end{array}$ & $\begin{array}{l}\text { Displ. } \\
\text { (in) }\end{array}$ & $\begin{array}{l}\text { Closure } \\
\text { (in) }\end{array}$ & $\begin{array}{l}\text { Extr. } \\
\text { (in) }\end{array}$ & $\begin{array}{l}\text { Com. } \\
\text { Rad. }\end{array}$ & BR & $\begin{array}{l}\text { Comments } \\
\text { Met. }\end{array}$ \\
\hline A098 & 344.8 & 1261 & 109.1 & 0.3146 & 0.2370 & 3467.0 & 554.6 & 0.822 & 0.0666 & 0.162 & 0.013 & & 1 & \\
\hline A099 & 344.0 & 1257 & 108.7 & 0.3090 & 0.2354 & 3456.3 & 523.9 & 0.813 & 0.0677 & 0.158 & 0.010 & & 2 & Disc. line \\
\hline A100 & 344.8 & 1255 & 108.6 & 0.2872 & 0.2232 & 3480.4 & 526.7 & 0.777 & 0.0681 & 0.145 & 0.002 & & 2 & Disc. line \\
\hline A106 & 344.4 & 1250 & 108.2 & 0.2960 & 0.2247 & 3475.1 & 524.9 & 0.781 & 0.0684 & 0.147 & 0.001 & & 2 & Disc. line \\
\hline A097 & 363.5 & 1252 & 108.3 & 0.2984 & 0.2220 & 3694.6 & 593.0 & 0.820 & 0.0662 & 0.168 & 0.010 & & 1 & Nugget \\
\hline A107 & 363.3 & 1254 & 108.5 & 0.2925 & 0.2214 & 3693.6 & 591.0 & 0.818 & 0.0673 & 0.167 & 0.011 & & 2 & Melting \\
\hline A108 & 363.1 & 1249 & 108.1 & 0.2938 & 0.2217 & 3693.5 & 588.5 & 0.819 & 0.0675 & 0.167 & 0.009 & & 2 & Disc line \\
\hline A095 & 381.7 & 1251 & 108.3 & 0.2934 & 0.2162 & 3898.6 & 639.2 & 0.843 & 0.0657 & 0.180 & 0.018 & & 1 & Nugget \\
\hline A104 & 377.9 & 1251 & 108.2 & 0.3021 & 0.2168 & 3859.8 & 623.5 & 0.837 & 0.0664 & 0.175 & 0.014 & & 1 & Nugget \\
\hline A105 & 382.9 & 1252 & 108.3 & 0.3082 & 0.2157 & 3916.4 & 642.6 & 0.845 & 0.0665 & 0.179 & 0.017 & & 1 & Nugget \\
\hline
\end{tabular}

Table 2. Type 316 weld conditions and results.

\begin{tabular}{|c|c|c|c|c|c|c|c|c|c|c|c|c|c|c|}
\hline$\overline{I D}$ & $\begin{array}{l}\text { Volt } \\
(\mathrm{V})\end{array}$ & $\begin{array}{l}\text { Force } \\
\text { (lbs) }\end{array}$ & $\begin{array}{l}\text { Press. } \\
\text { (psi) }\end{array}$ & $\begin{array}{l}\text { Stat. } \\
\text { Res. } \\
(\mathrm{m} \Omega)\end{array}$ & $\begin{array}{l}\text { Dyn. } \\
\text { Res. } \\
(\mathrm{m} \Omega)\end{array}$ & $\begin{array}{l}\text { Weld } \\
\text { Current } \\
\text { (A) }\end{array}$ & $\begin{array}{l}\text { Weld } \\
\text { Energy } \\
(\mathrm{J})\end{array}$ & $\begin{array}{l}\text { Weld } \\
\text { Volt } \\
\text { (V) }\end{array}$ & $\begin{array}{l}\text { Displ. } \\
\text { (in) }\end{array}$ & $\begin{array}{l}\text { Closure } \\
\text { (in) }\end{array}$ & $\begin{array}{l}\text { Extr. } \\
\text { (in) }\end{array}$ & $\begin{array}{l}\text { Comm. } \\
\text { Rad. }\end{array}$ & 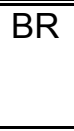 & $\begin{array}{l}\text { Comments } \\
\text { Met. }\end{array}$ \\
\hline B078 & 330.1 & 1251 & 108.3 & 0.3162 & 0.2376 & 3421.9 & 541.4 & 0.813 & 0.0661 & 0.147 & 0.005 & & 2 & Melting \\
\hline B079 & 330.6 & 1253 & 108.5 & 0.3144 & 0.2408 & 3300.5 & 510.9 & 0.795 & 0.0659 & 0.134 & 0.002 & & 2 & $\begin{array}{l}\text { Almost } \\
\text { Cont line }\end{array}$ \\
\hline B080 & 330.9 & 1250 & 108.2 & 0.3185 & 0.2419 & 3301.2 & 513.7 & 0.799 & 0.0648 & 0.136 & 0.001 & & 2 & Disc line \\
\hline B089 & 331.2 & 1252 & 108.3 & 0.3144 & 0.2415 & 3307.9 & 515.3 & 0.799 & 0.0658 & 0.140 & 0.003 & & 2 & Disc line \\
\hline B076 & 346.8 & 1250 & 108.2 & 0.3180 & 0.2386 & 3480.4 & 562.4 & 0.830 & 0.0653 & 0.156 & 0.010 & & 1 & Nugget \\
\hline B077 & 346.9 & 1255 & 108.7 & 0.3177 & 0.2363 & 3481.4 & 557.3 & 0.823 & 0.0665 & 0.157 & 0.006 & & 1 & Nugget \\
\hline B081 & 346.8 & 1255 & 108.6 & 0.3073 & 0.2366 & 3480.8 & 560.4 & 0.824 & 0.0661 & 0.152 & 0.007 & & 2 & Disc line \\
\hline B082 & 363.6 & 1255 & 108.6 & 0.3123 & 0.2287 & 3668.8 & 598.7 & 0.839 & 0.0646 & 0.166 & 0.013 & & 1 & Nugget \\
\hline B083 & 363.4 & 1250 & 108.1 & 0.3175 & 0.2291 & 3666.3 & 598.7 & 0.840 & 0.0657 & 0.169 & 0.015 & & 1 & Nugget \\
\hline B084 & 363.7 & 1253 & 108.5 & 0.3267 & 0.2317 & 3669.3 & 608.9 & 0.850 & 0.0652 & 0.169 & 0.018 & & 1 & Nugget \\
\hline
\end{tabular}


Table 3. 21-6-9 weld conditions and results.

\begin{tabular}{|c|c|c|c|c|c|c|c|c|c|c|c|c|c|c|}
\hline$\overline{I I D}$ & $\begin{array}{l}\text { Volt } \\
\text { (V) }\end{array}$ & $\begin{array}{l}\text { Force } \\
\text { (Ibs) }\end{array}$ & $\begin{array}{l}\text { Press. } \\
\text { (psi) }\end{array}$ & $\begin{array}{l}\text { Stat. } \\
\text { Res. } \\
(\mathrm{m} \Omega)\end{array}$ & $\begin{array}{l}\text { Dyn. } \\
\text { Res. } \\
(\mathrm{m} \Omega)\end{array}$ & $\begin{array}{l}\text { Weld } \\
\text { Current } \\
\text { (A) }\end{array}$ & $\begin{array}{l}\text { Weld } \\
\text { Energy } \\
(\mathrm{J})\end{array}$ & $\begin{array}{l}\text { Weld } \\
\text { Volt } \\
(\mathrm{V}) \\
\end{array}$ & $\begin{array}{l}\text { Displ. } \\
\text { (in) }\end{array}$ & $\begin{array}{l}\text { Closure } \\
\text { (in) }\end{array}$ & $\begin{array}{l}\text { Extr. } \\
\text { (in) }\end{array}$ & $\begin{array}{l}\text { Comm. } \\
\text { Rad. }\end{array}$ & $\overline{\mathrm{BR}}$ & $\begin{array}{l}\text { Comments } \\
\text { Met. }\end{array}$ \\
\hline C137 & 347.7 & 1498 & 128.8 & 0.2887 & 0.2244 & 3522.3 & 542.3 & 0.790 & 0.0670 & 0.159 & 0.006 & & 2 & Disc. line \\
\hline C138 & 347.7 & 1499 & 128.9 & 0.3087 & 0.2297 & 3515.0 & 552.2 & 0.807 & 0.0661 & 0.165 & 0.010 & & 1 & Nugget \\
\hline C140 & 347.4 & 1498 & 128.7 & 0.3062 & 0.2312 & 3512.3 & 561.7 & 0.812 & 0.0666 & 0.165 & 0.011 & & 1 & Nugget \\
\hline C141 & 347.4 & 1499 & 128.9 & 0.3125 & 0.2325 & 3513.1 & 558.3 & 0.817 & 0.0656 & 0.168 & 0.011 & & 1 & Nugget \\
\hline C142 & 358.1 & 1503 & 129.2 & 0.3050 & 0.2247 & 3625.9 & 571.2 & 0.815 & 0.0654 & 0.171 & 0.013 & & 1 & Nugget \\
\hline C144 & 358.1 & 1498 & 128.7 & 0.2993 & 0.2257 & 3630.6 & 578.7 & 0.819 & 0.0657 & 0.172 & 0.012 & & 1 & Nugget \\
\hline C146 & 358.4 & 1503 & 129.1 & 0.3089 & 0.2259 & 3630.9 & 578.8 & 0.820 & 0.0651 & 0.173 & 0.013 & & 1 & Nugget \\
\hline C139 & 370.1 & 1500 & 128.9 & 0.3045 & 0.2203 & 3771.0 & 594.4 & 0.831 & 0.0660 & 0.177 & 0.014 & & 1 & Nugget \\
\hline C143 & 369.8 & 1499 & 128.8 & 0.2946 & 0.2194 & 3764.8 & 607.9 & 0.826 & 0.0652 & 0.179 & 0.013 & & 1 & Nugget \\
\hline C149 & 370.1 & 1498 & 128.7 & 0.2910 & 0.2188 & 3767.0 & 603.3 & 0.824 & 0.0656 & 0.178 & 0.015 & & 1 & Nugget \\
\hline
\end{tabular}


Table 4. Comparison of weld metrics and weld quality metrics for the two oils.

\begin{tabular}{|c|c|c|c|c|c|c|c|c|c|c|c|}
\hline \multicolumn{6}{|c|}{ Set-up Welds 50-50 Oil } & \multicolumn{6}{|c|}{ Castrol Oil } \\
\hline $\begin{array}{l}304 \mathrm{~L} \\
\text { ID } \\
\end{array}$ & $\begin{array}{l}\text { Volt } \\
(\mathrm{V}) \\
\end{array}$ & $\begin{array}{l}\text { Weld } \\
\text { Current } \\
\text { (A) }\end{array}$ & $\begin{array}{l}\text { Closure } \\
\text { (in) }\end{array}$ & $\mathrm{BR}$ & $\begin{array}{l}\text { Met } \\
\text { Com. }\end{array}$ & ID & $\begin{array}{l}\text { Volt } \\
\text { (V) }\end{array}$ & $\begin{array}{l}\text { Weld } \\
\text { Current } \\
\text { (A) }\end{array}$ & $\begin{array}{l}\text { Clos. } \\
\text { (in) }\end{array}$ & BR & $\begin{array}{l}\text { Met } \\
\text { Com. }\end{array}$ \\
\hline $\mathrm{X} 0119$ & 345.7 & 3467 & 0.162 & 2 & Disc line & A098 & 344.8 & 3467 & 0.162 & 1 & \\
\hline X0116 & 345.7 & 3469 & 0.154 & 2 & Disc line & A099 & 344.0 & 3456.3 & 0.158 & 2 & Disc. line \\
\hline & & & & & & A100 & 344.8 & 3480.4 & 0.145 & 2 & Disc. line \\
\hline & & & & & & A106 & 344.4 & 3475.1 & 0.147 & 2 & Disc. line \\
\hline & & & & & & A097 & 363.5 & 3694.6 & 0.168 & 1 & Nugget \\
\hline & & & & & & A107 & 363.3 & 3693.6 & 0.167 & 2 & Melting \\
\hline & & & & & & A108 & 363.1 & 3693.5 & 0.167 & 2 & Disc line \\
\hline & & & & & & A095 & 381.7 & 3898.6 & 0.180 & 1 & Nugget \\
\hline $\mathrm{X} 0115$ & 381.5 & 3876 & 0.180 & 1 & Nugget & A104 & 377.9 & 3859.8 & 0.175 & 1 & Nugget \\
\hline $\mathrm{X} 0120$ & 381.9 & 3870 & 0.183 & 1 & Nugget & A105 & 382.9 & 3916.4 & 0.179 & 1 & Nugget \\
\hline $\begin{array}{r}316 \\
\text { ID }\end{array}$ & $\begin{array}{l}\text { Volt } \\
(\mathrm{V})\end{array}$ & $\begin{array}{l}\text { Weld } \\
\text { Current } \\
\text { (A) }\end{array}$ & $\begin{array}{l}\text { Closure } \\
\text { (in) }\end{array}$ & $\overline{B R}$ & $\begin{array}{l}\text { Met } \\
\text { Com. }\end{array}$ & ID & $\begin{array}{l}\text { Volt } \\
\text { (V) }\end{array}$ & $\begin{array}{l}\text { Weld } \\
\text { Current } \\
\text { (A) }\end{array}$ & $\begin{array}{l}\text { Clos. } \\
\text { (in) }\end{array}$ & BR & $\begin{array}{l}\text { Met } \\
\text { Com. }\end{array}$ \\
\hline B051 & 330.3 & 3315.5 & 0.145 & 2 & $\begin{array}{l}\text { Disc line } \\
\text { with melt }\end{array}$ & B078 & 330.1 & 3421.9 & 0.147 & 2 & Melting \\
\hline B053 & 330.6 & 3317.9 & 0.147 & 2 & $\begin{array}{l}\text { Disc line } \\
\text { with melt }\end{array}$ & B079 & 330.6 & 3300.5 & 0.134 & 2 & $\begin{array}{l}\text { Almost } \\
\text { Cont line }\end{array}$ \\
\hline & & & & & & B080 & 330.9 & 3301.2 & 0.136 & 2 & Disc line \\
\hline & & & & & & B089 & 331.2 & 3307.9 & 0.140 & 2 & Disc line \\
\hline B050 & 344.2 & 3448 & 0.154 & 2 & $\begin{array}{l}\text { Disc line } \\
\text { with melt }\end{array}$ & B076 & 346.8 & 3480.4 & 0.156 & 1 & Nugget \\
\hline B057 & 344.4 & 3447 & 0.155 & 2 & $\begin{array}{l}\text { Disc line } \\
\text { with melt }\end{array}$ & B077 & 346.9 & 3481.4 & 0.157 & 1 & Nugget \\
\hline B058 & 344.4 & 3449 & 0.156 & 2 & $\begin{array}{l}\text { Disc line } \\
\text { with melt }\end{array}$ & B081 & 346.8 & 3480.8 & 0.152 & 2 & Disc line \\
\hline B055 & 363.7 & 3668 & 0.170 & 1 & Nugget & B082 & 363.6 & 3668.8 & 0.166 & 1 & Nugget \\
\hline B059 & 363.9 & 3672 & 0.168 & 1 & Nugget & B083 & 363.4 & 3666.3 & 0.169 & 1 & Nugget \\
\hline B060 & 364.2 & 3672 & 0.17 & 1 & Nugget & B084 & 363.7 & 3669.3 & 0.169 & 1 & Nugget \\
\hline $\begin{array}{l}21-6-9 \\
\text { ID } \\
\end{array}$ & $\begin{array}{l}\text { Volt } \\
(\mathrm{V}) \\
\end{array}$ & $\begin{array}{l}\text { Weld } \\
\text { Current } \\
\text { (A) }\end{array}$ & $\begin{array}{l}\text { Closure } \\
\text { (in) }\end{array}$ & $\mathrm{BR}$ & $\begin{array}{l}\text { Met } \\
\text { Com. }\end{array}$ & ID & $\begin{array}{l}\text { Volt } \\
(\mathrm{V})\end{array}$ & $\begin{array}{l}\text { Weld } \\
\text { Current } \\
\text { (A) }\end{array}$ & $\begin{array}{l}\text { Clos. } \\
\text { (in) }\end{array}$ & $B R$ & $\begin{array}{l}\text { Met } \\
\text { Com. }\end{array}$ \\
\hline C103 & 347.1 & 3495 & 0.161 & 2 & Disc line & C137 & 347.7 & 3522.3 & 0.159 & 2 & Disc. line \\
\hline C104 & 347.2 & 3491 & 0.161 & 2 & Disc line & C138 & 347.7 & 3515 & 0.165 & 1 & Nugget \\
\hline C101 & 347.4 & 3497 & 0.158 & 3 & $\begin{array}{l}\text { Almost } \\
\text { cont line }\end{array}$ & C140 & 347.4 & 3512.3 & 0.165 & 1 & Nugget \\
\hline & & & & & & C141 & 347.4 & 3513.1 & 0.168 & 1 & Nugget \\
\hline & & & & & & C142 & 358.1 & 3625.9 & 0.171 & 1 & Nugget \\
\hline & & & & & & C144 & 358.1 & 3630.6 & 0.172 & 1 & Nugget \\
\hline & & & & & & C146 & 358.4 & 3630.9 & 0.173 & 1 & Nugget \\
\hline C105 & 369.9 & 3744 & 0.177 & 1 & Nugget & C139 & 370.1 & 3771 & 0.177 & 1 & Nugget \\
\hline C102 & 370.7 & 3758 & 0.180 & 1 & Nugget & C143 & 369.8 & 3764.8 & 0.179 & 1 & Nugget \\
\hline C109 & 371 & 3760 & 0.180 & 1 & Nugget & C149 & 370.1 & 3767 & 0.178 & 1 & Nugget \\
\hline
\end{tabular}


Appendix A Fill stem manufacturing changes and pinch weld qualifications

SRNL-MST-2007-00066

Fill Stem Manufacturing Changes and Pinch Weld Qualifications

To: C. Cadden, B. Meyer, K. Arnold, D. Grote, J. McGrath, W. West, S. Mazurek, J. McCowan, S. West, M. Dupont, D. Maxwell

Based on previous discussions from the Stem Team the following protocol is recommended to ensure that manufacturing changes that are not expected to result in the need for a full qualification in the tritium facility. In order to accomplish this task with the fewest reasonable number of stems, the following plan is tendered:

1. Determine weld conditions on the SRNL prototypic welder for 316 stainless steel fill stems that produce class 1 and 2 bonds. Test stems of the PRJ706566-102 will be used. The stems will be machined with 50/50 cutting oil

A. Preliminary conditions for 316 based on email dated 3-6-07 from B. West 3/16” electrode, 1250 lbs +/- 50 lbs, current from 3300-3700 A for WR weld conditions

Weld in 2 atm of Nitrogen or deuterium

Weld one stem each at $3300 \mathrm{~A}$ and 3500A and 3700A

Proof test at $40 \mathrm{ksi}$

$\mathrm{X}$-ray for closure length, extrusion, and geometry

Transverse metallographic examination

B. Based on these conditions either increase or decrease current (voltage) range for welds, weld a new set to if range is changed.

Weld three 50/50 test stems at the low and high conditions, with current at low and force at high and current at high with force low, to ensure suitable weld parameters

2. Determine weld conditions on the SRNL prototypic welder for 21-6-9 stainless steel fill stems that produce class 1 and 2 bonds.

A. Preliminary conditions for 21-6-9 based on email dated 3-6-07 from B. West 3/16” electrode, 1500 lbs, current from 3750 to 4150 A for WR weld conditions (this simulates $\mathrm{M}$ conditions).

Weld one stem each at $3750 \mathrm{~A}, 3950 \mathrm{~A}$, and 4150A

Weld in 2 atmospheres of Nitrogen or deuterium

Proof test at $60 \mathrm{KSI}$

$\mathrm{X}$-ray for closure length, extrusion, and geometry

Transverse metallographic examination

B. Based on these conditions either increase or decrease current (voltage) range for welds.

Weld three 50/50 test stems at the low and high conditions, with current at low and force at high and current at high with force low, to ensure suitable weld parameters

3. Use current range established during fill stem project for 304L (3500-3900) A. 
Based on these conditions weld three 50/50 test stems at the low and high conditions, with current at low and force at high and current at high with force low, to ensure suitable weld parameters

Using these conditions, weld a total of ten stems of each material manufactured using modified, i.e., changed cutting oil, process. Weld four stems at "cold" condition, three at midpoint (nominal) condition, and three at "hot" condition, varying force opposite of current. Use standard suite of non-destructive and destructive tests to ensure acceptable quality.

Upon successful completion of these tasks, issue report(s) detailing the work that was completed and circulate to stakeholders. Include recommendation indicating approval of process for WR components.

The Tritium Facility will weld qualification stems as part of their normal quality assurance program for equipment validation prior to loading reservoirs. A full re-qualification of the process will not be required.

Test stems needed:

\begin{tabular}{|c|c|c|c|}
\hline Type & Quantity & Cutting Fluid & Purpose \\
\hline $21-6-9$ & 6 & $50 / 50$ & Weld window tuning \\
\hline $21-6-9$ & 6 & $50 / 50$ & Low and high validation \\
\hline $21-6-9$ & 12 & New & Process verification (and 2 contingency) \\
\hline 316 & 6 & $50 / 50$ & Weld window tuning \\
\hline 316 & 6 & $50 / 50$ & Low and high validation \\
\hline 316 & 12 & New & Process verification (and 2 contingency) \\
\hline 304L & 6 & $50 / 50$ & Low and high validation \\
\hline 304L & 12 & New & Process verification (and 2 contingency) \\
\hline
\end{tabular}


Appendix B. Microstructures of 304L Stainless Steel pinch welds
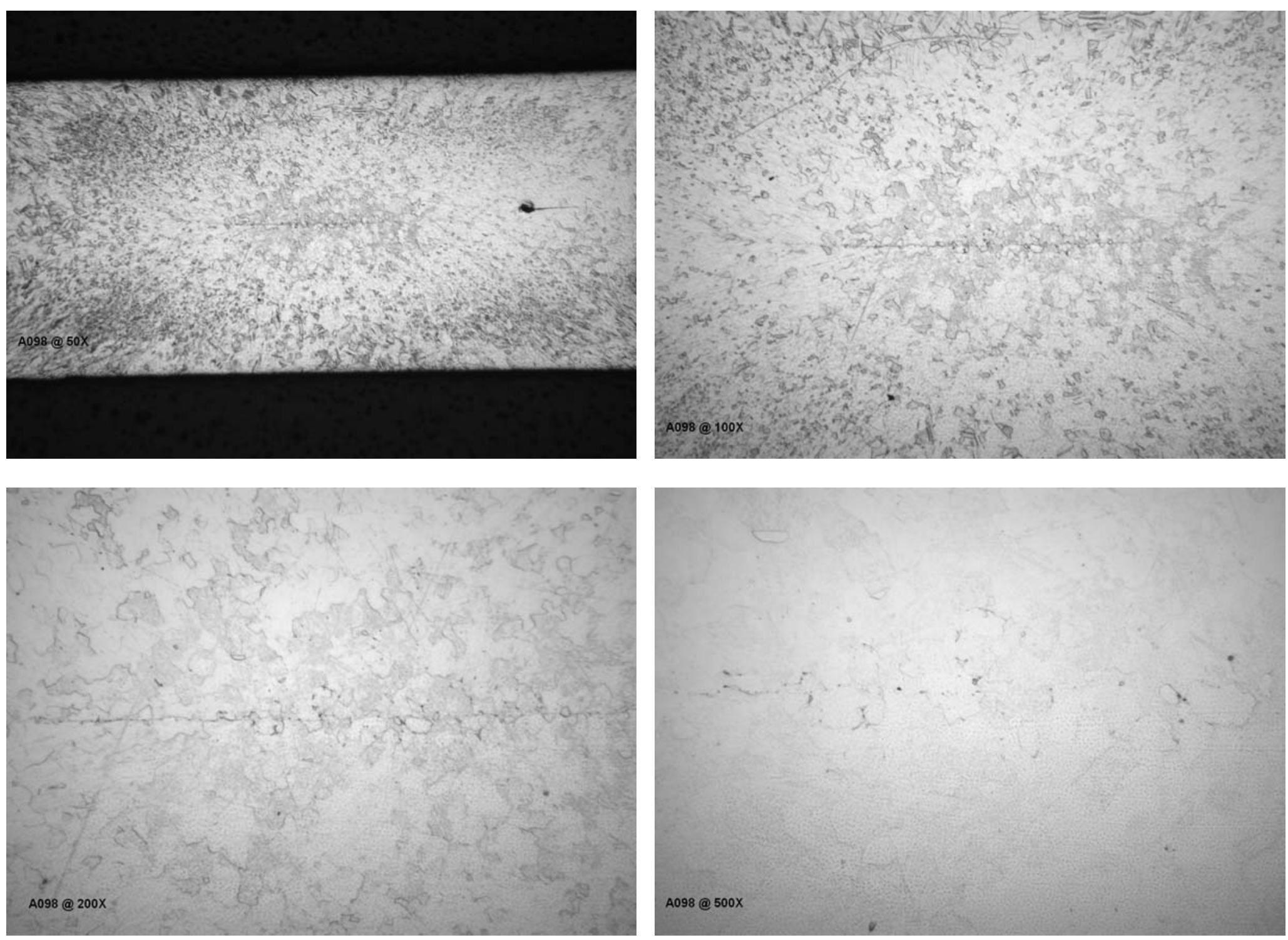

A098 Cold 

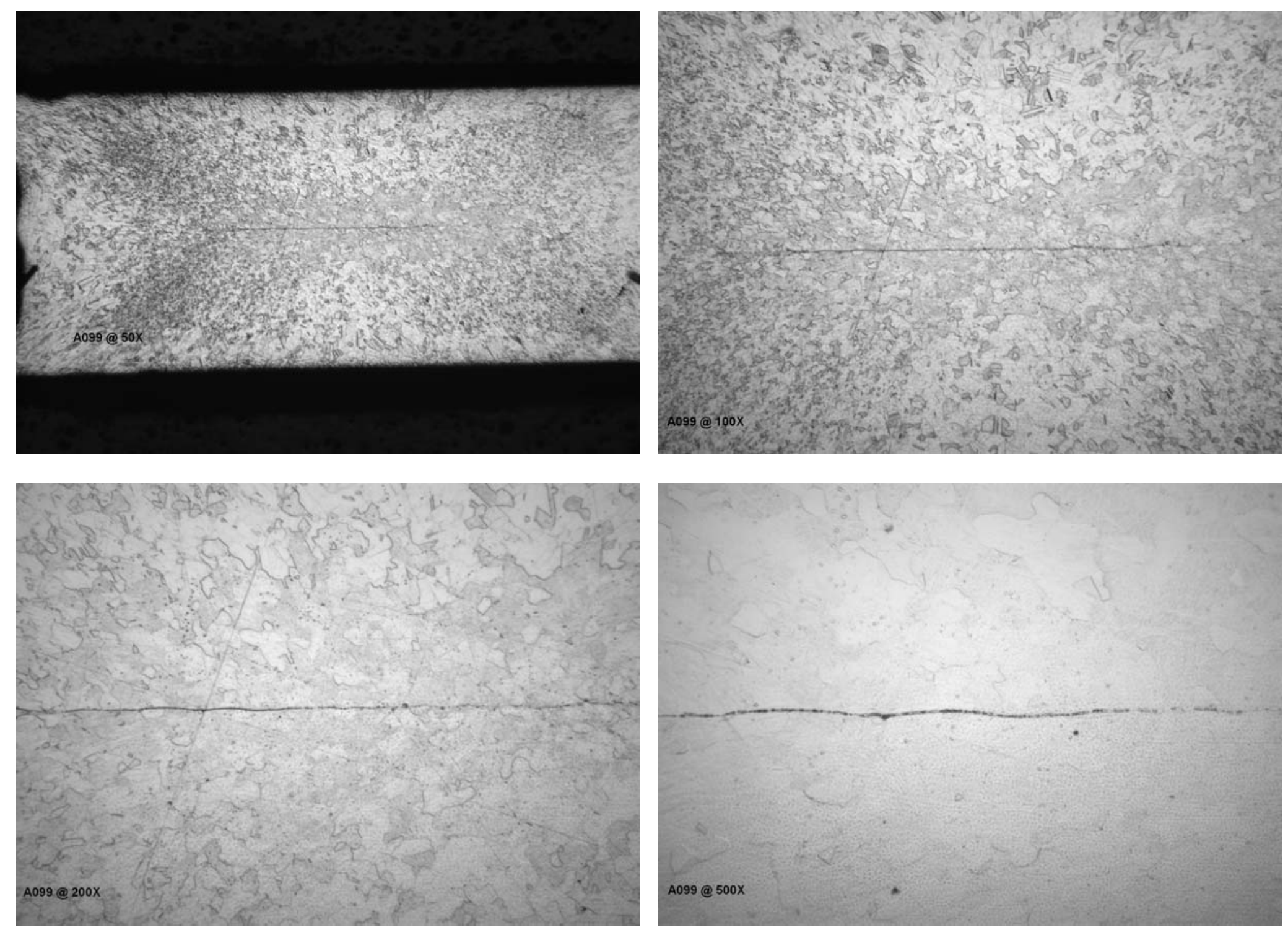

A099 Cold 

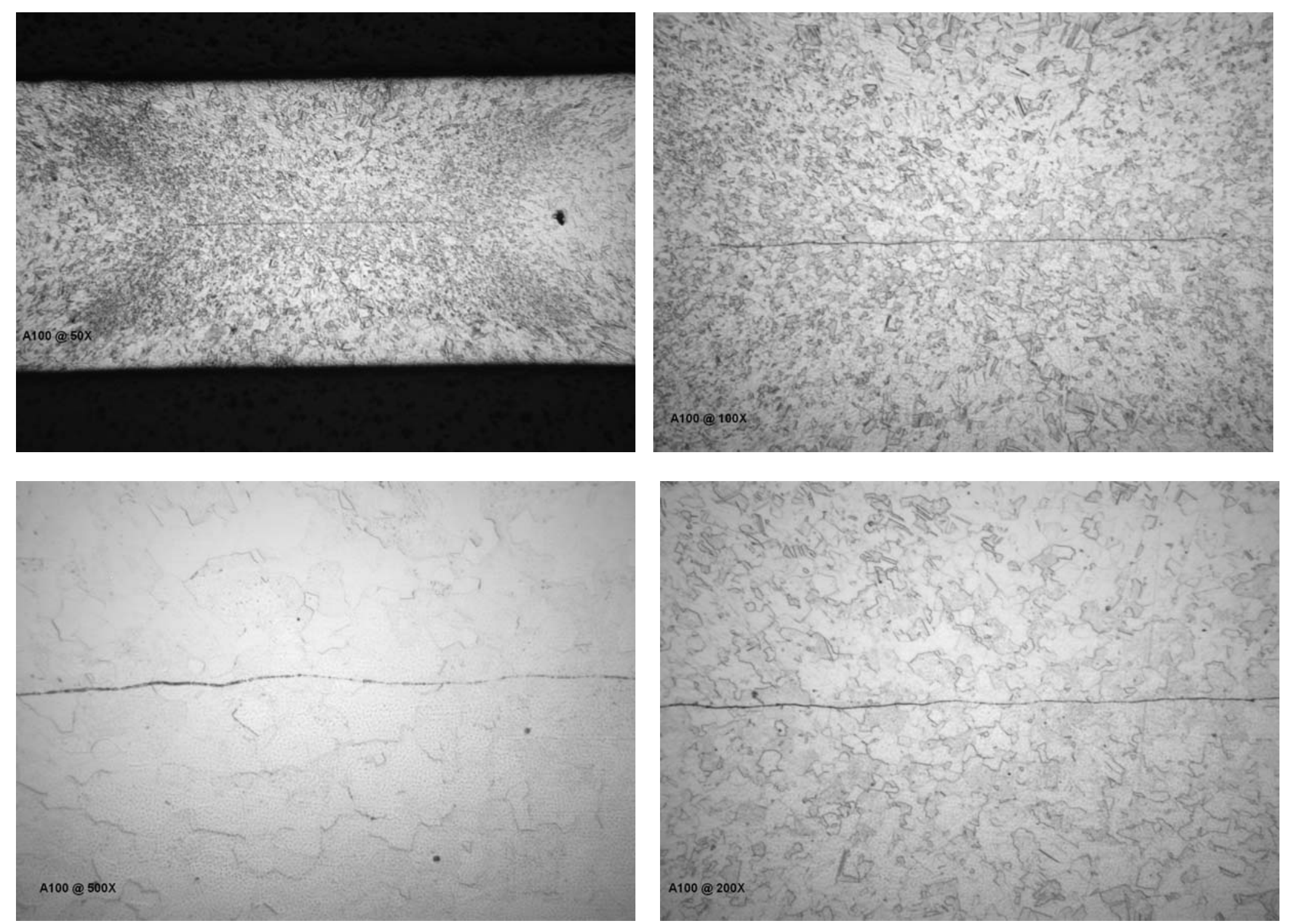

A100 Cold 

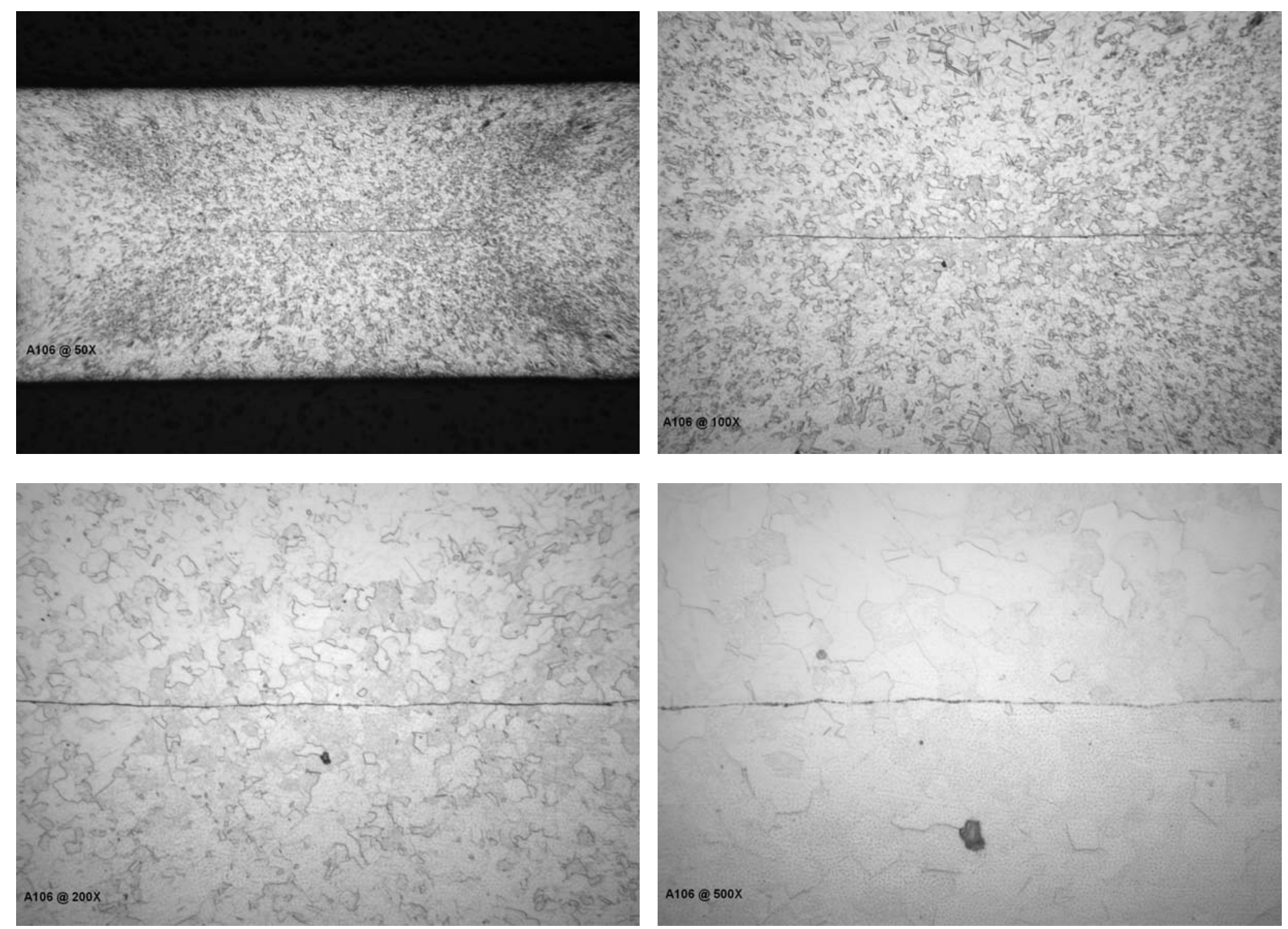

A106 Cold 

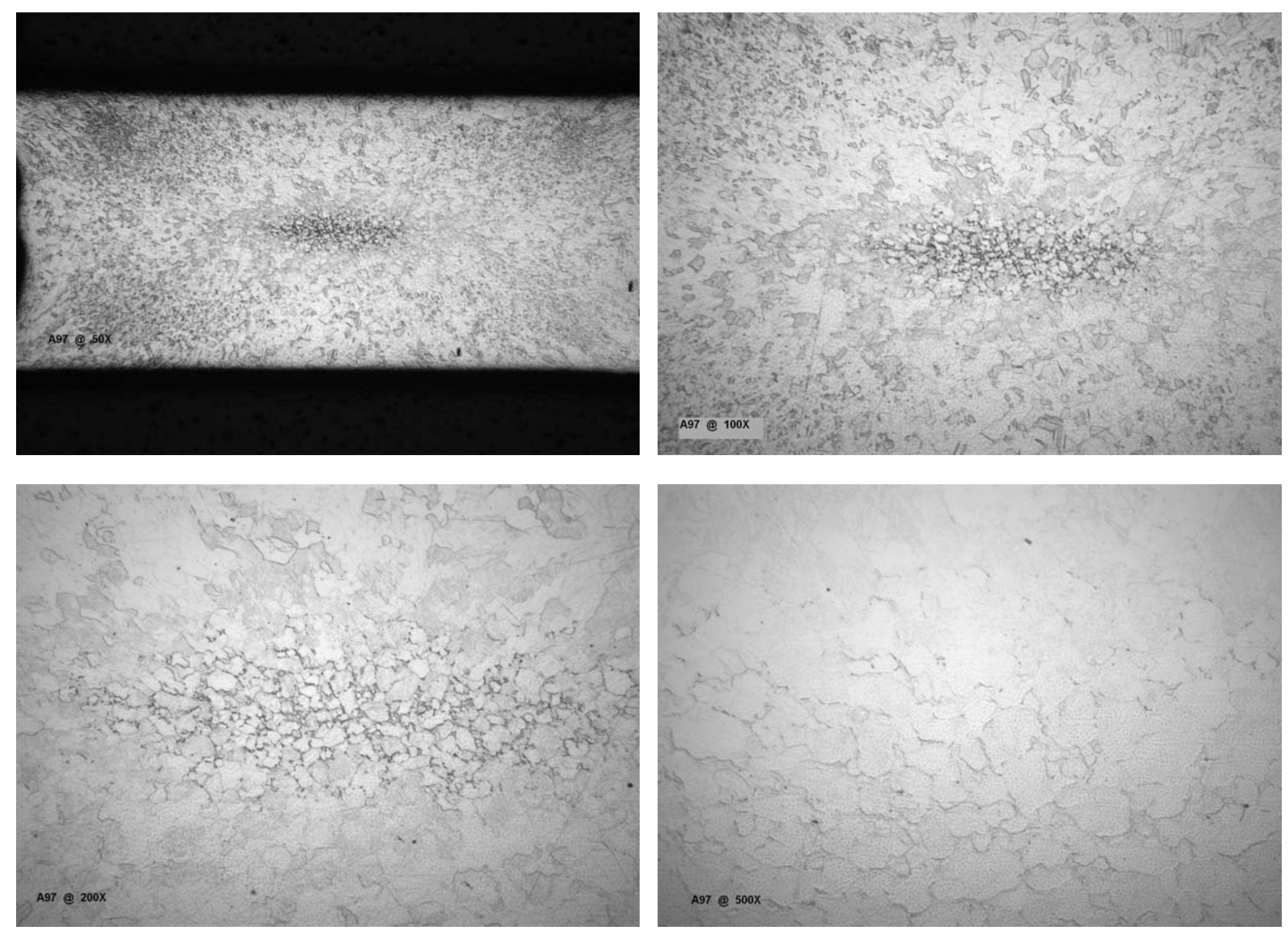

A097 Nominal 

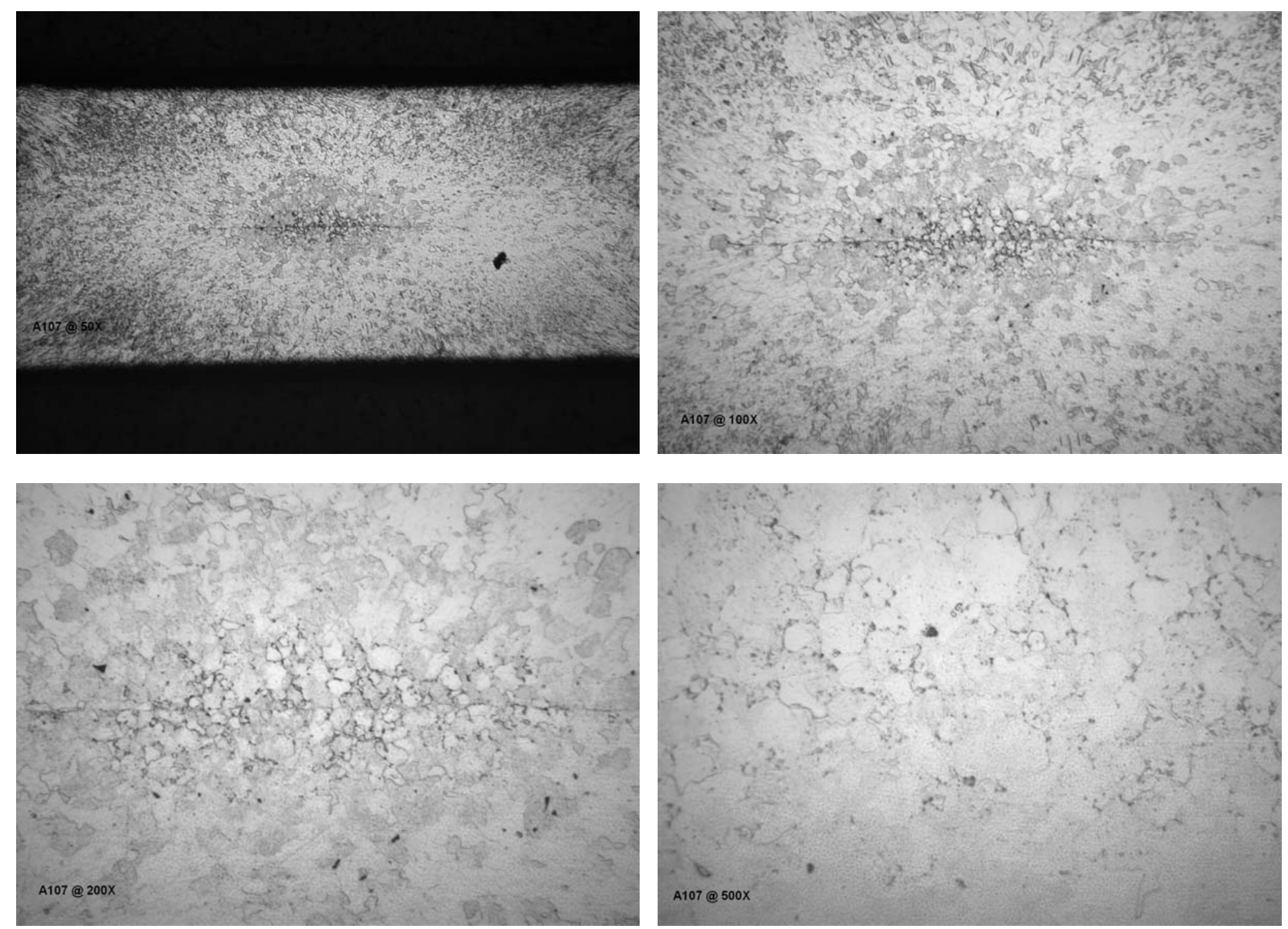

A107 Nominal 

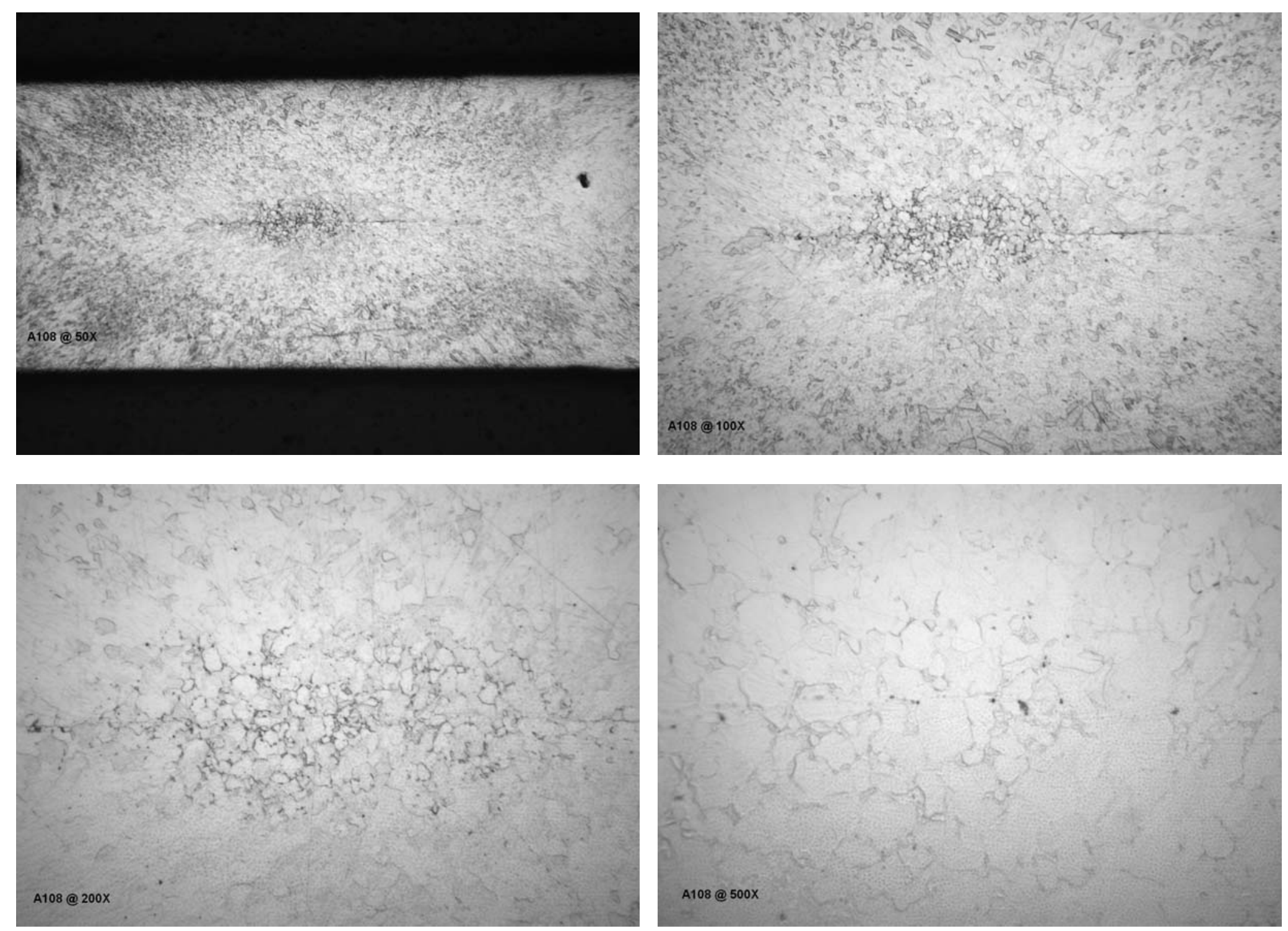

A108 Nominal 

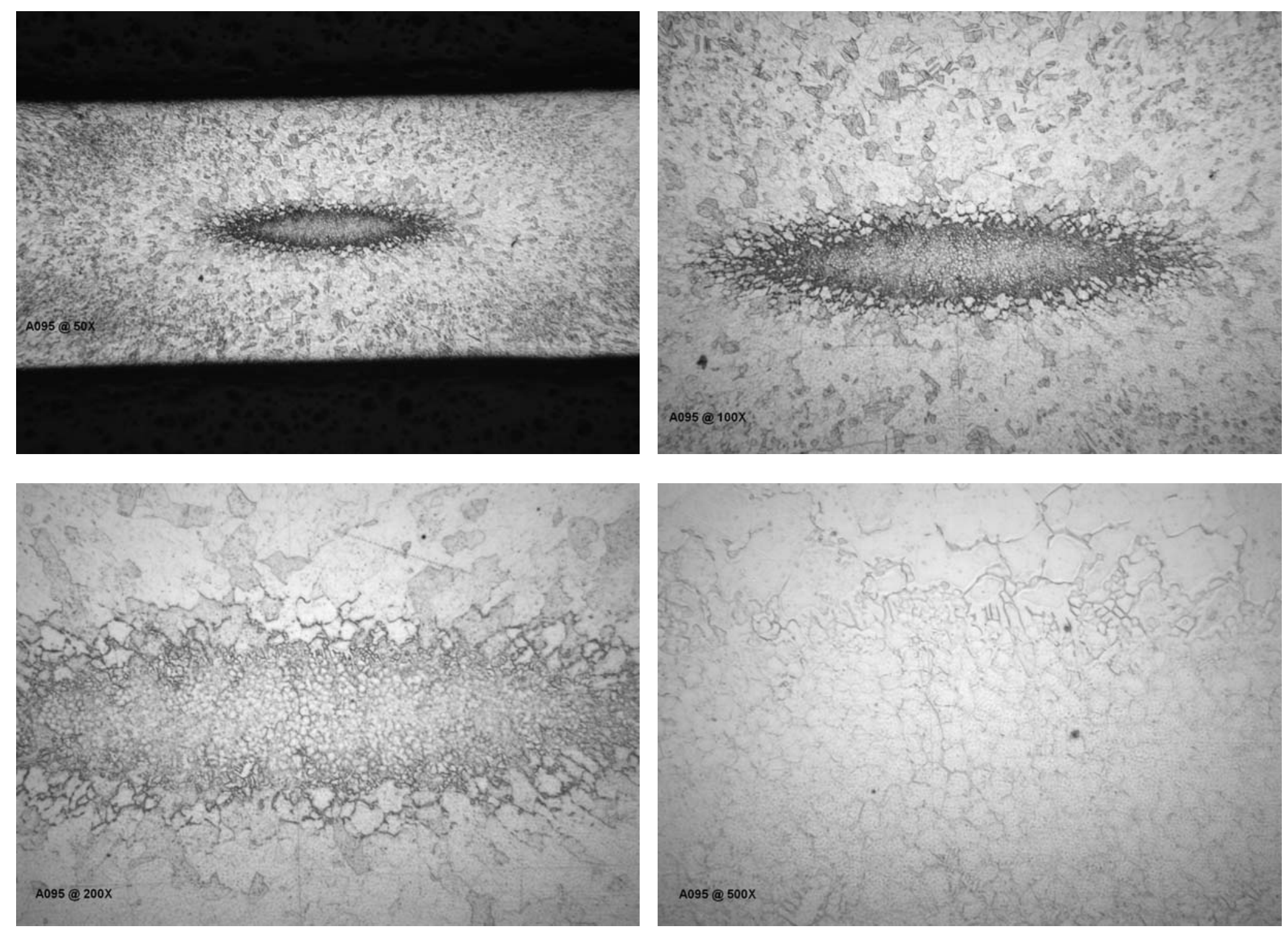

A095 Hot 

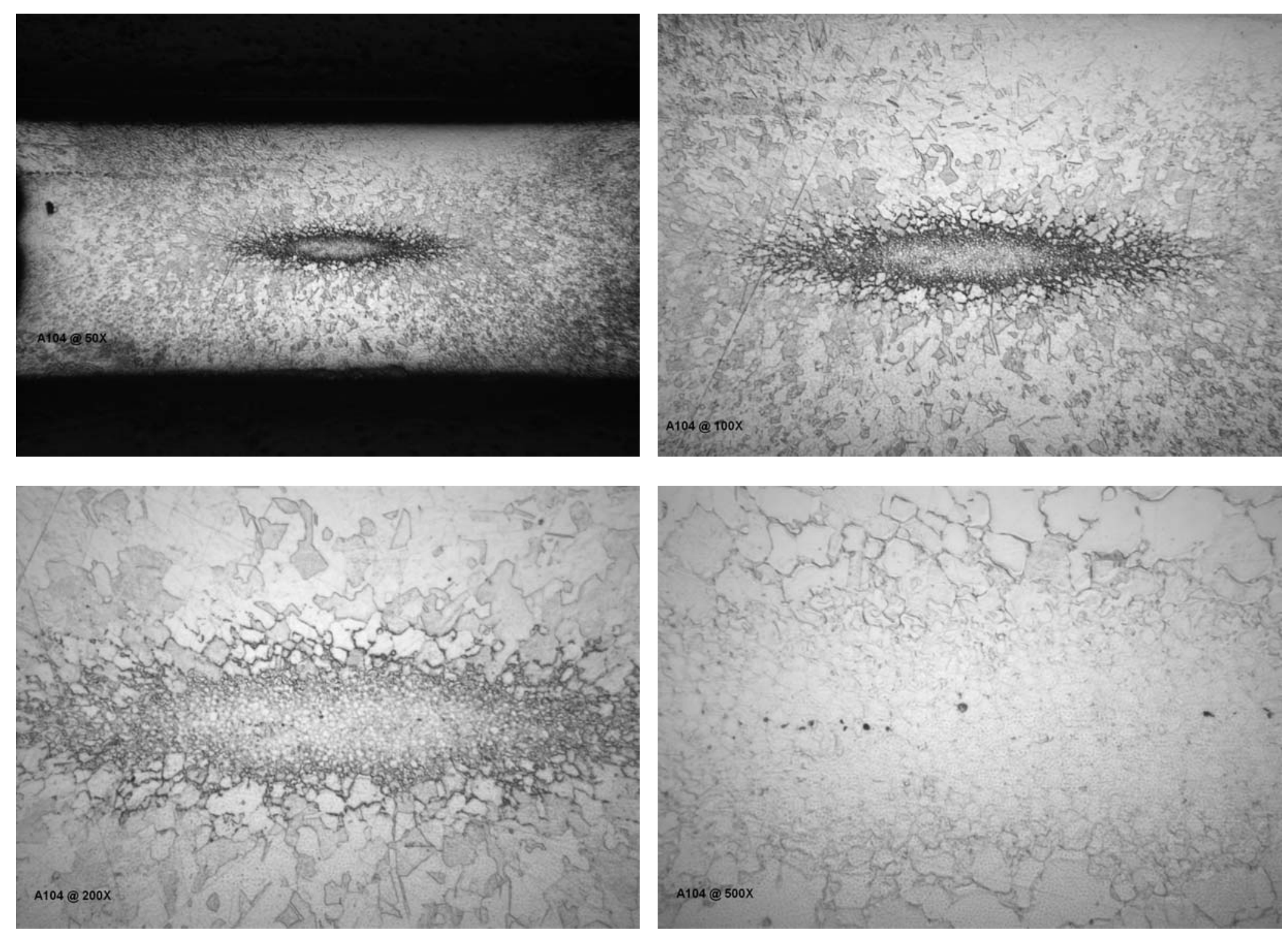

A104 Hot 

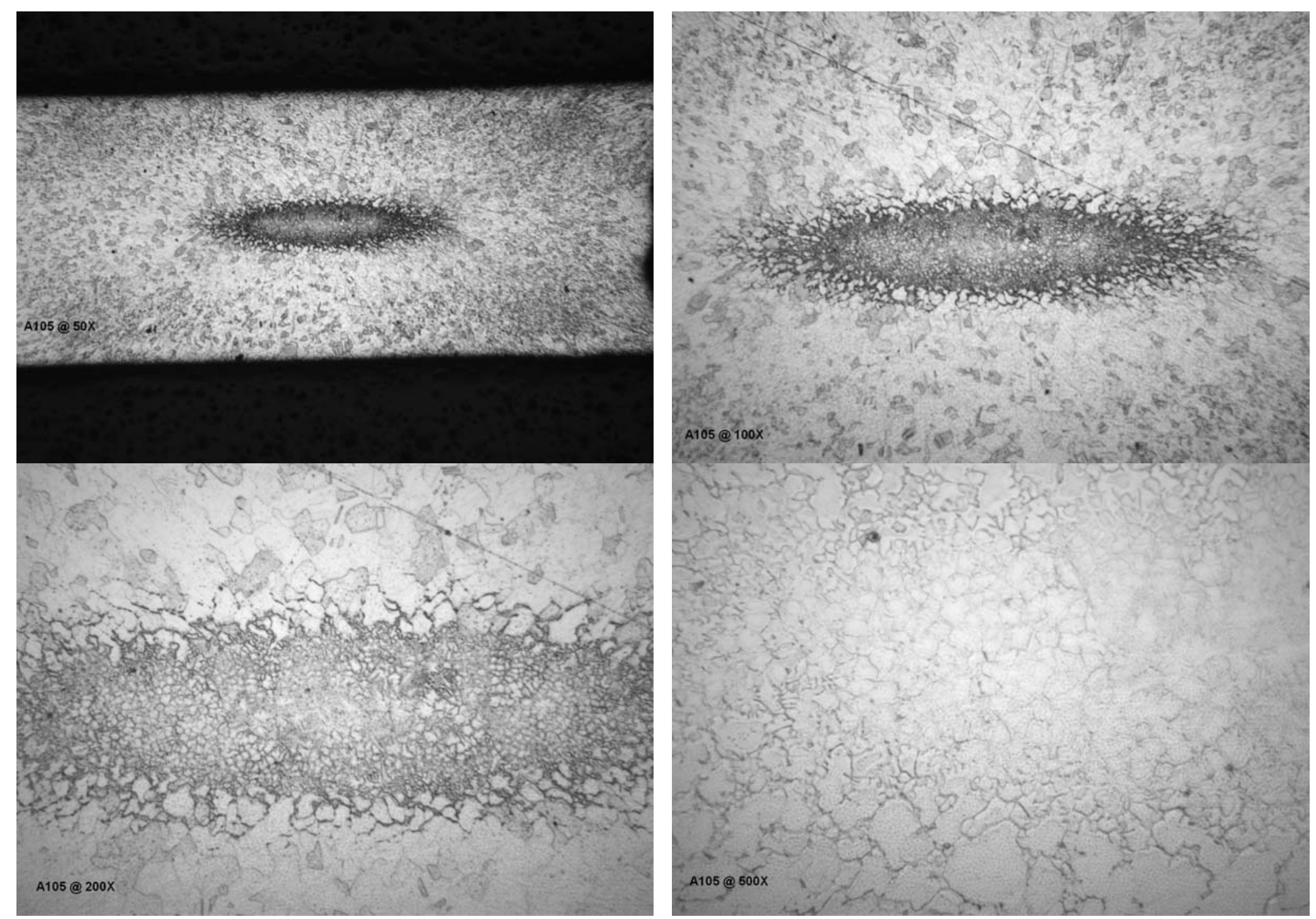

A105 Hot 
Appendix C. Type 316 Stainless Steel pinch weld microstructures.
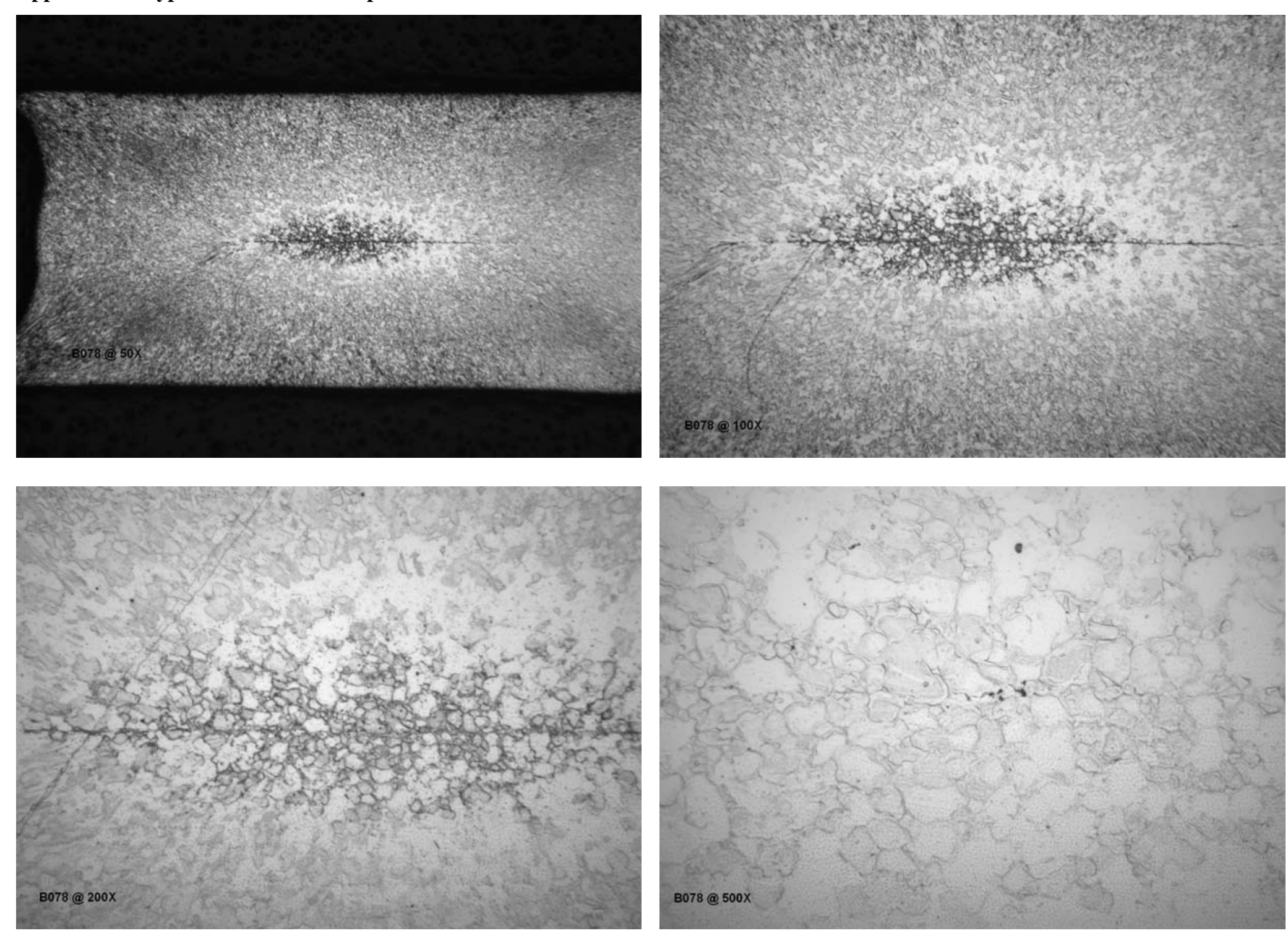

B078 Cold 

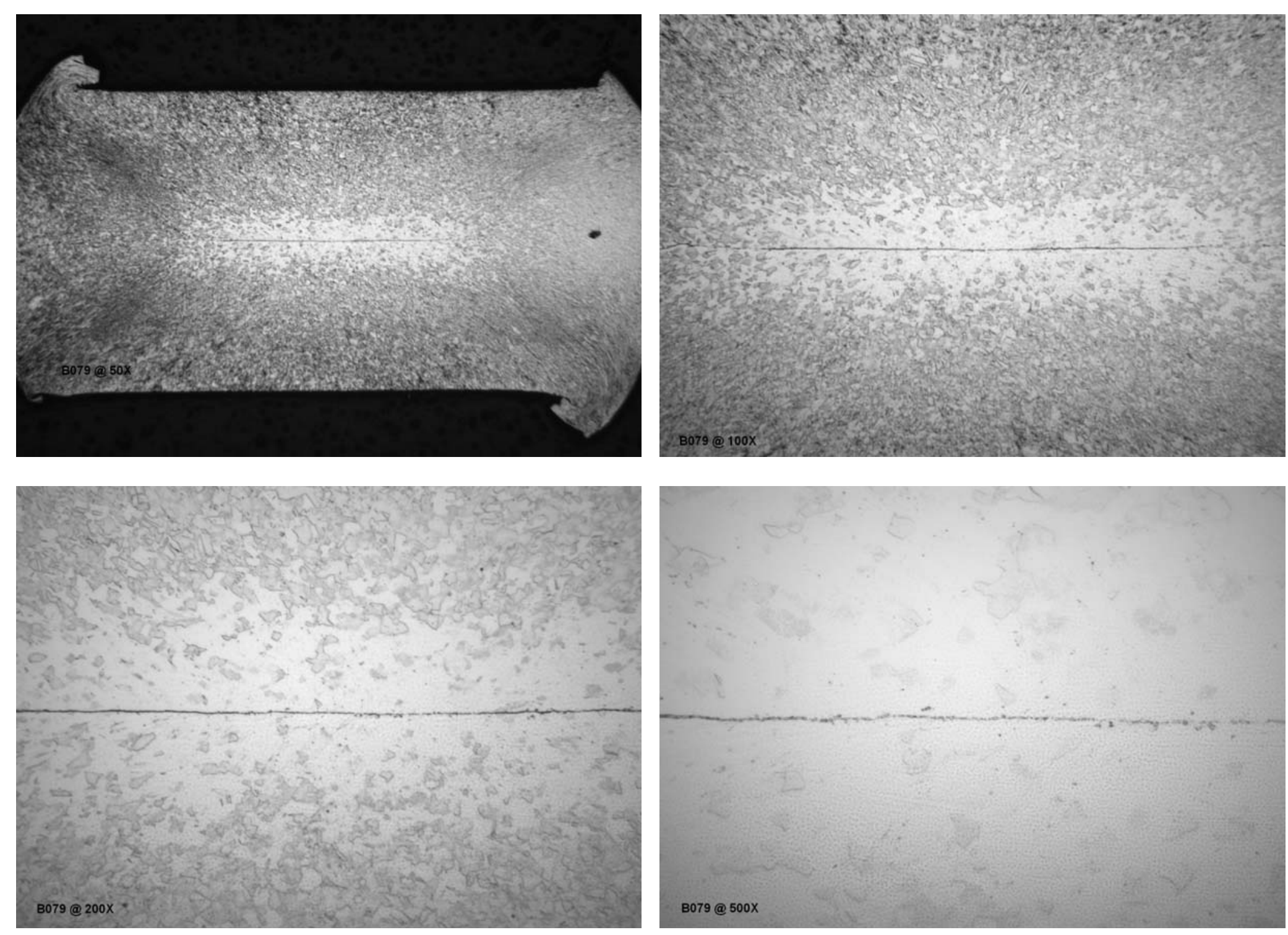

B079 Cold 

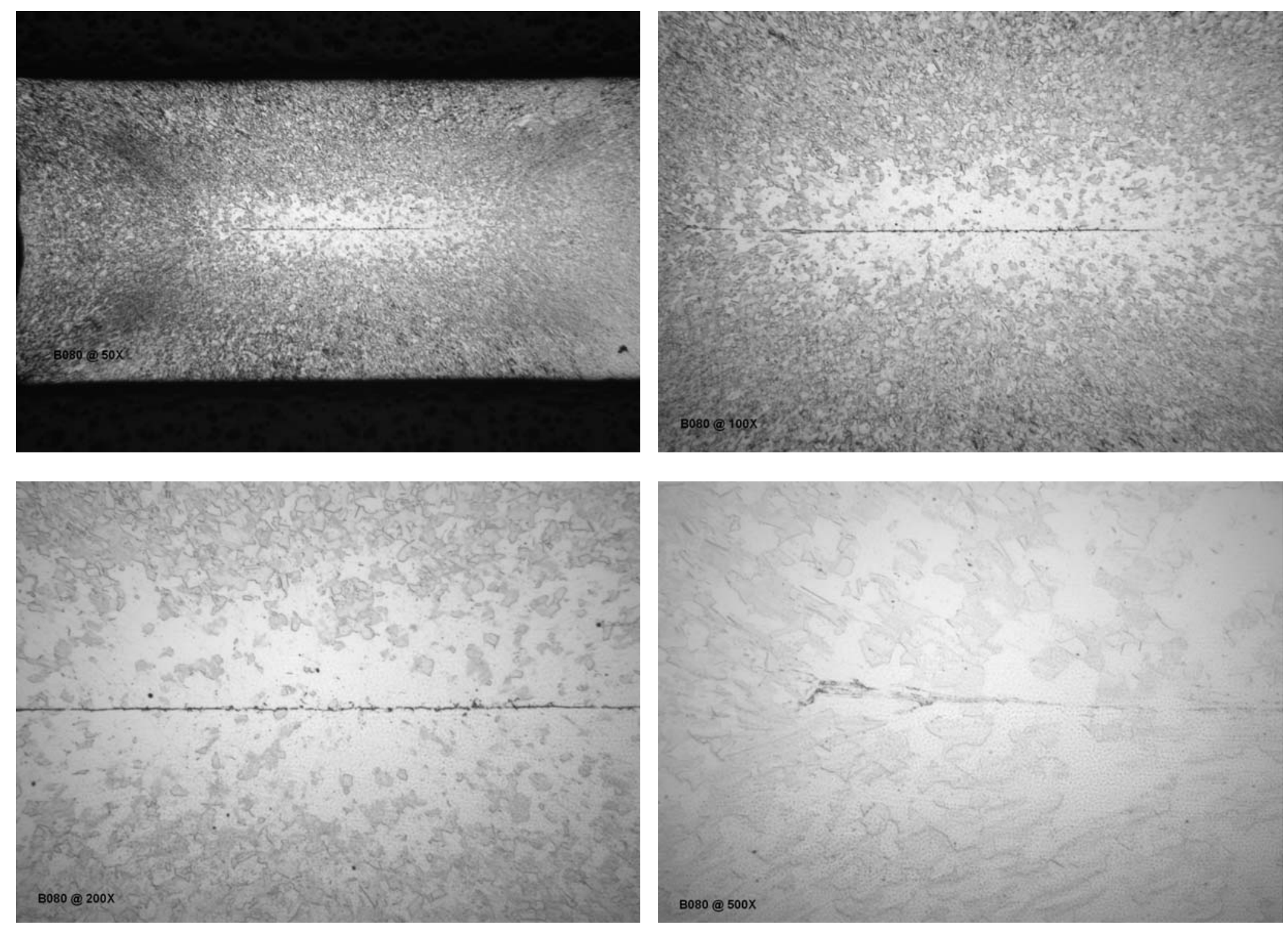

B080 Cold 

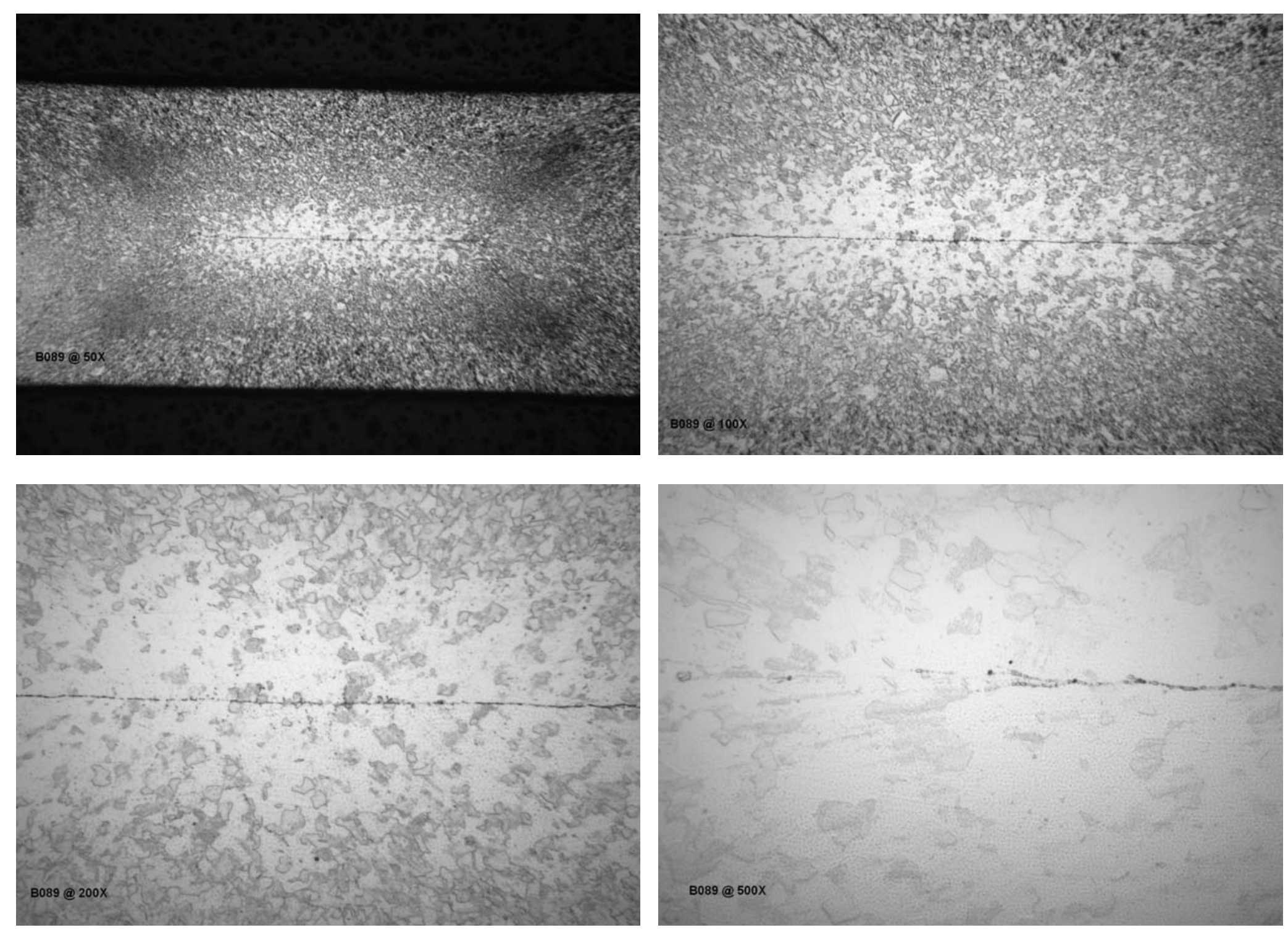

B089 Cold 

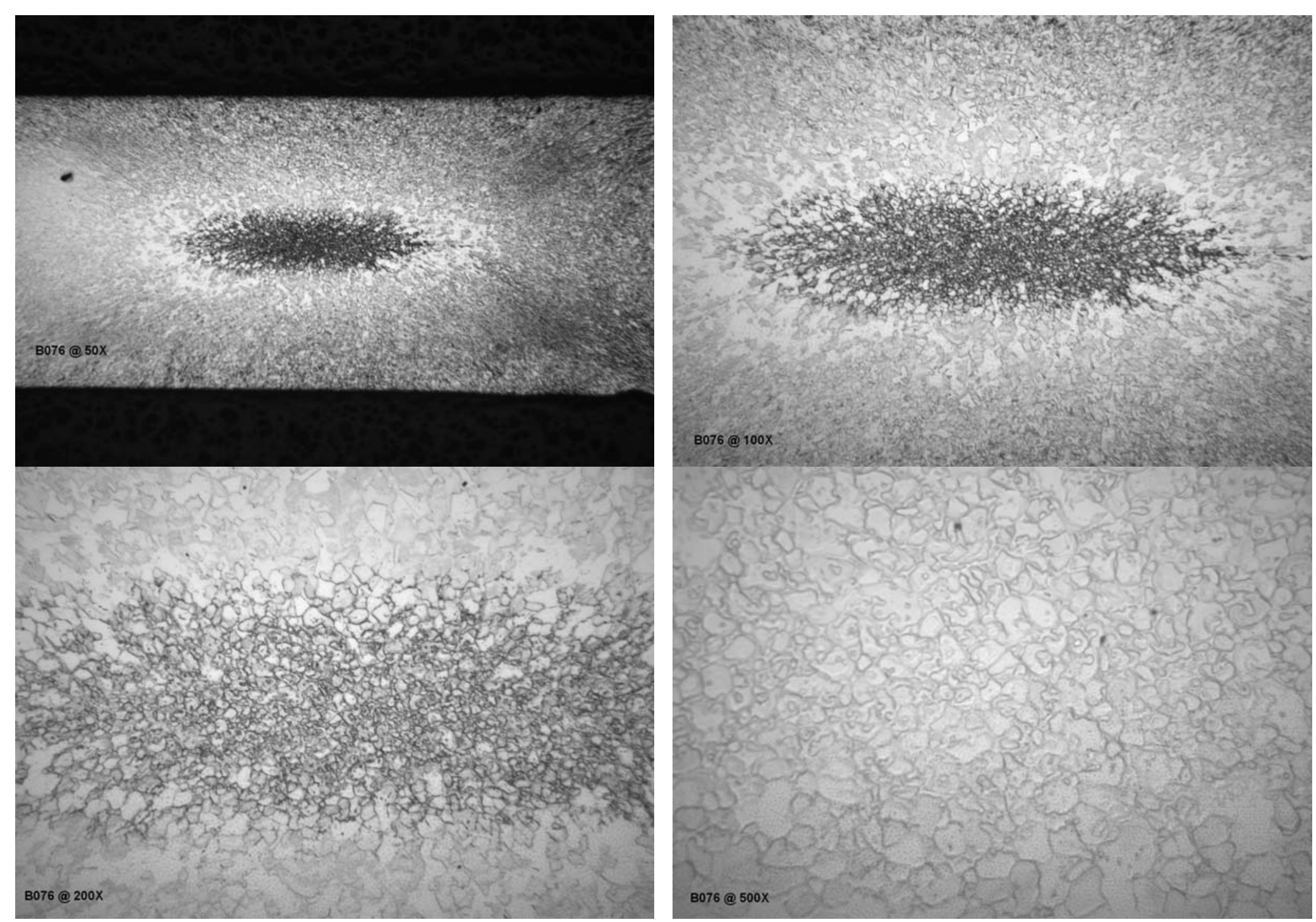

B076 Nominal 

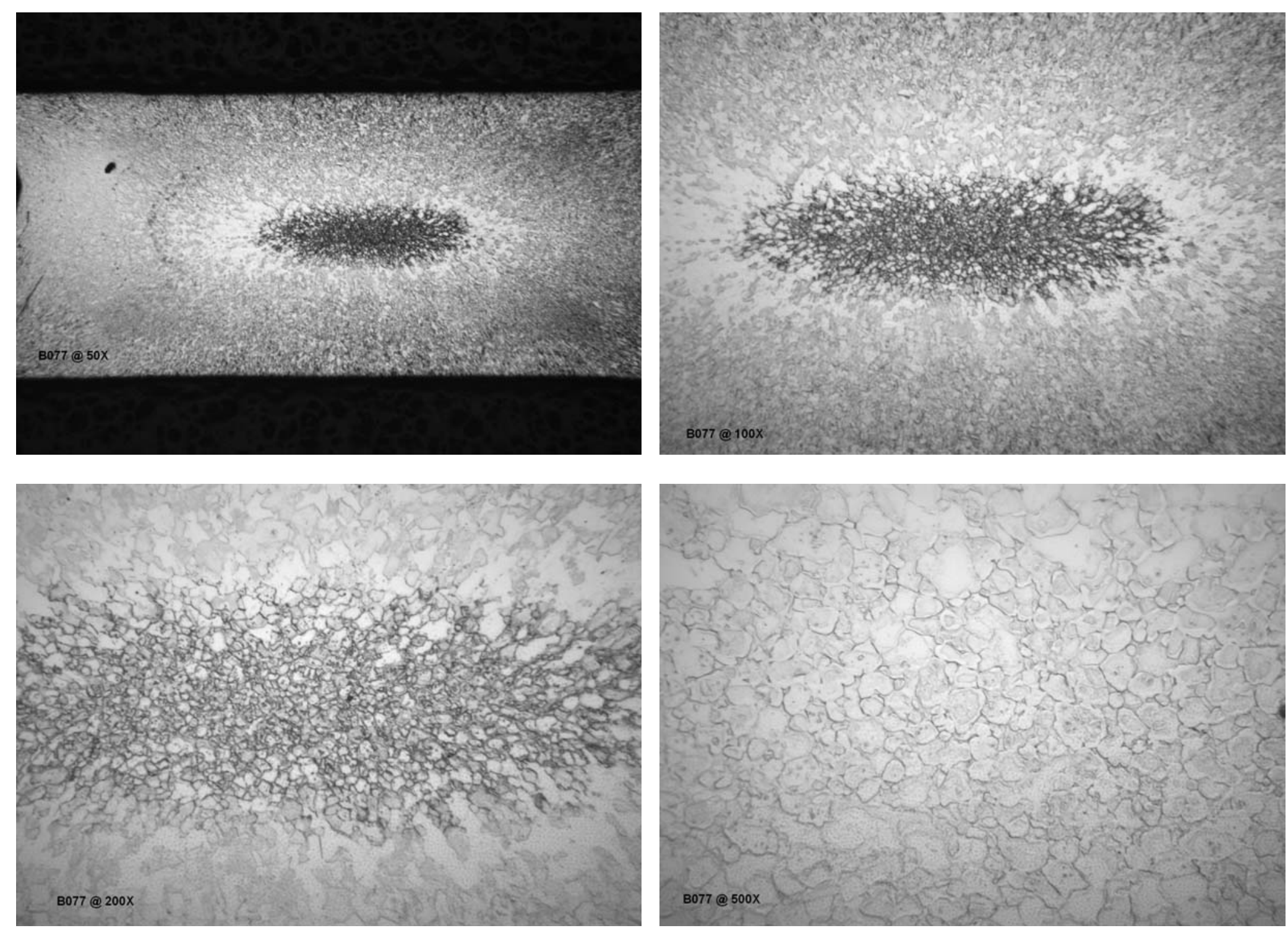

B077 Nominal 

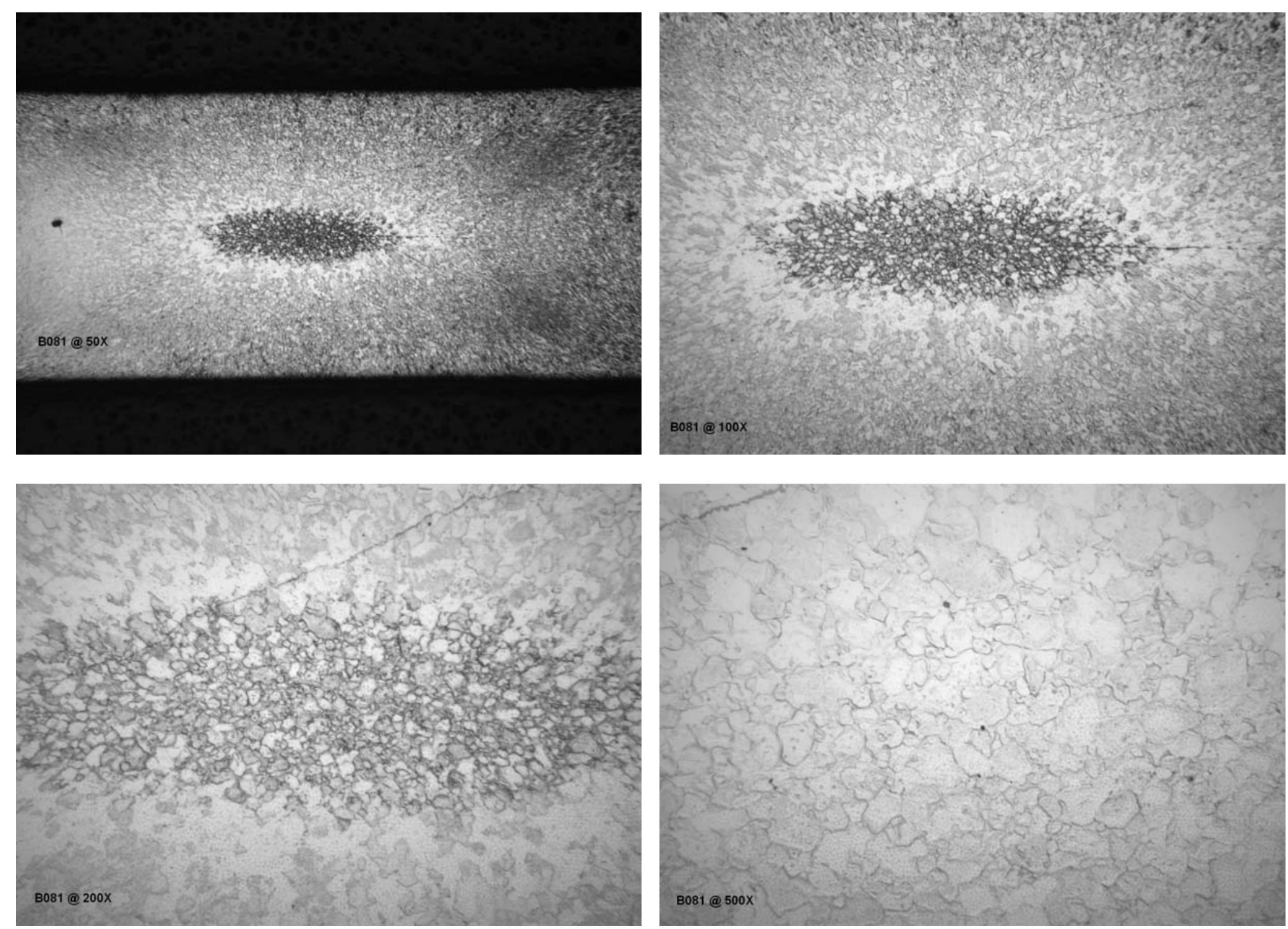

B081 Nominal 

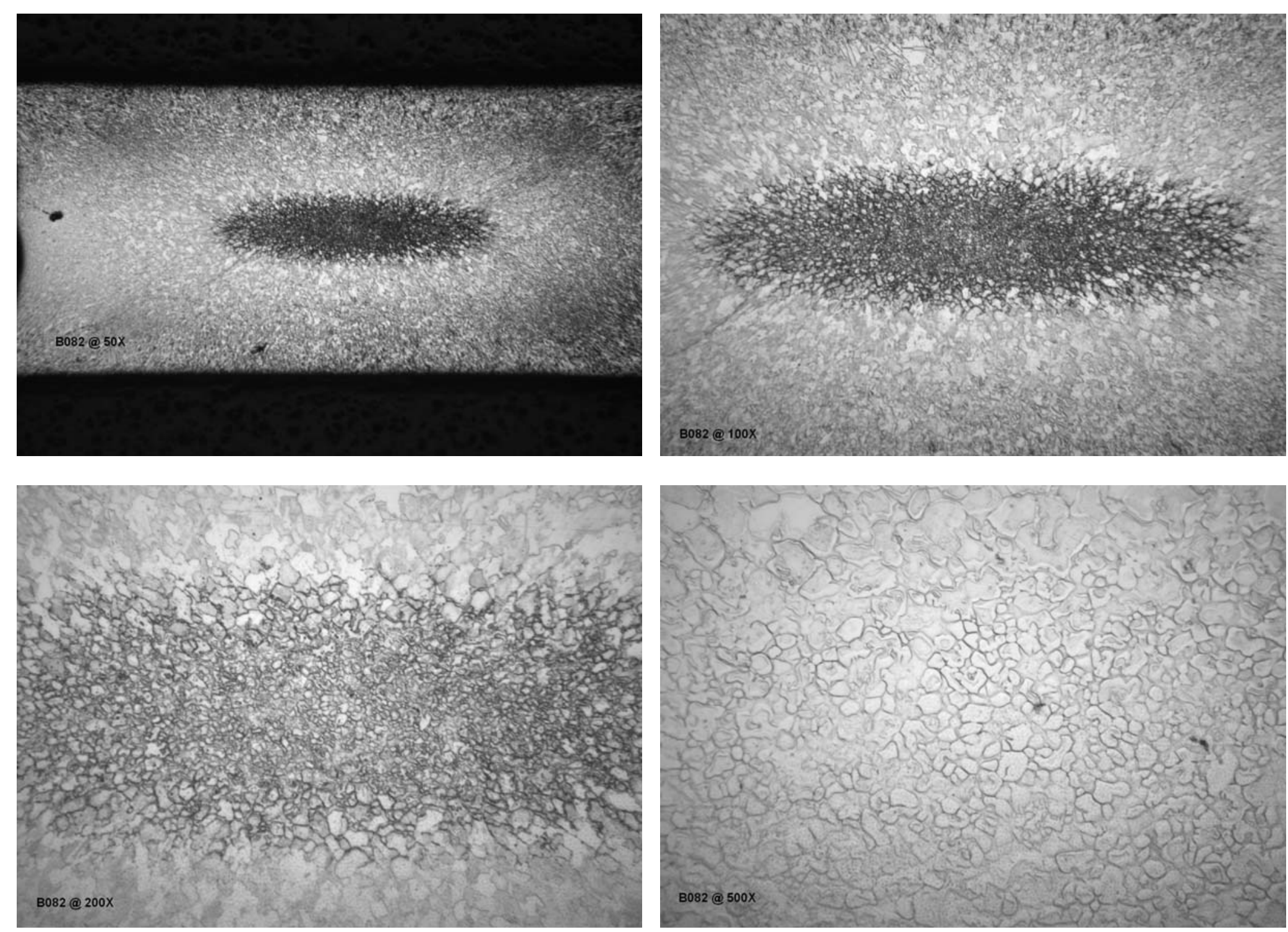

B082 Hot 

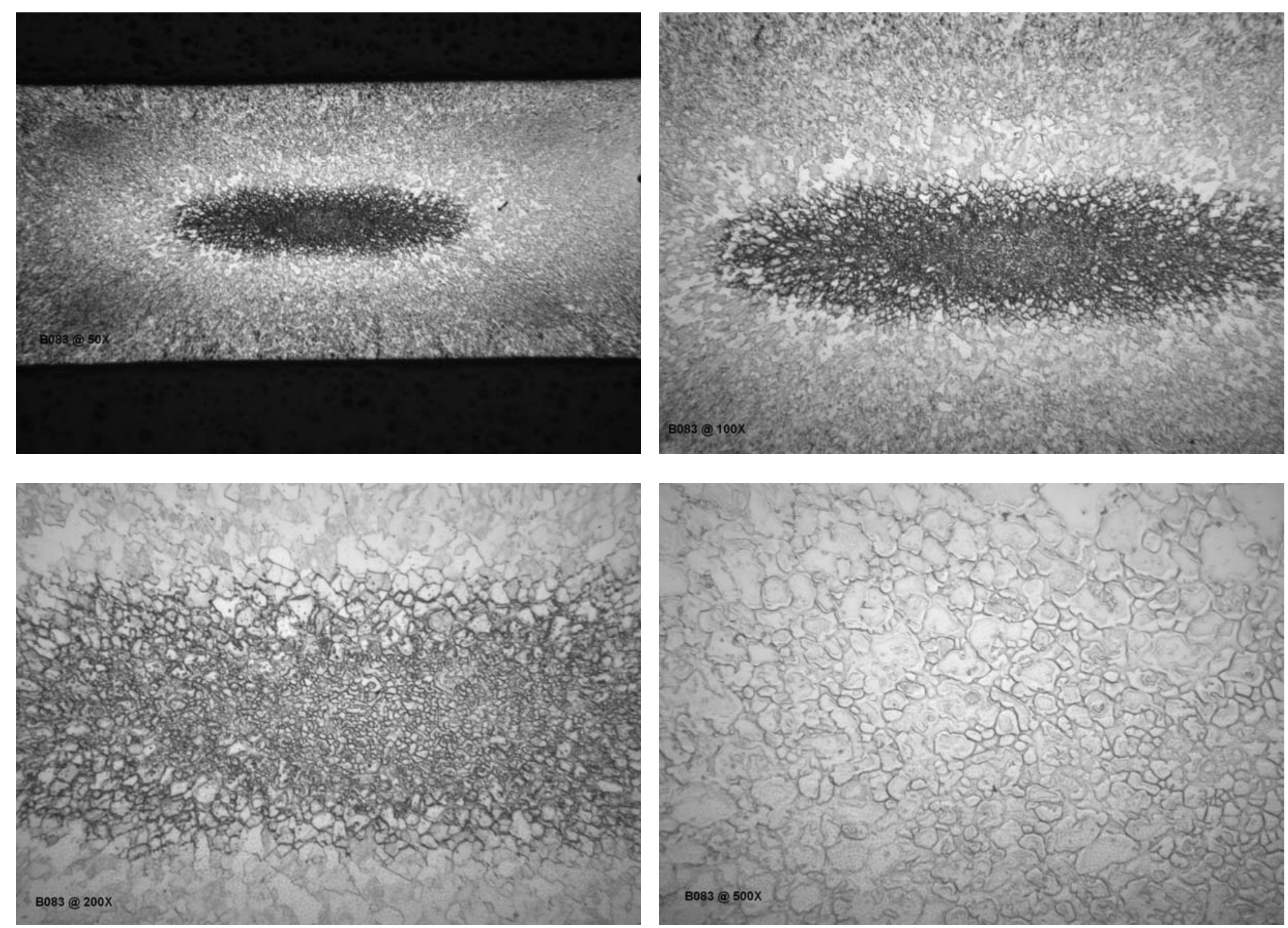

B083 Hot 

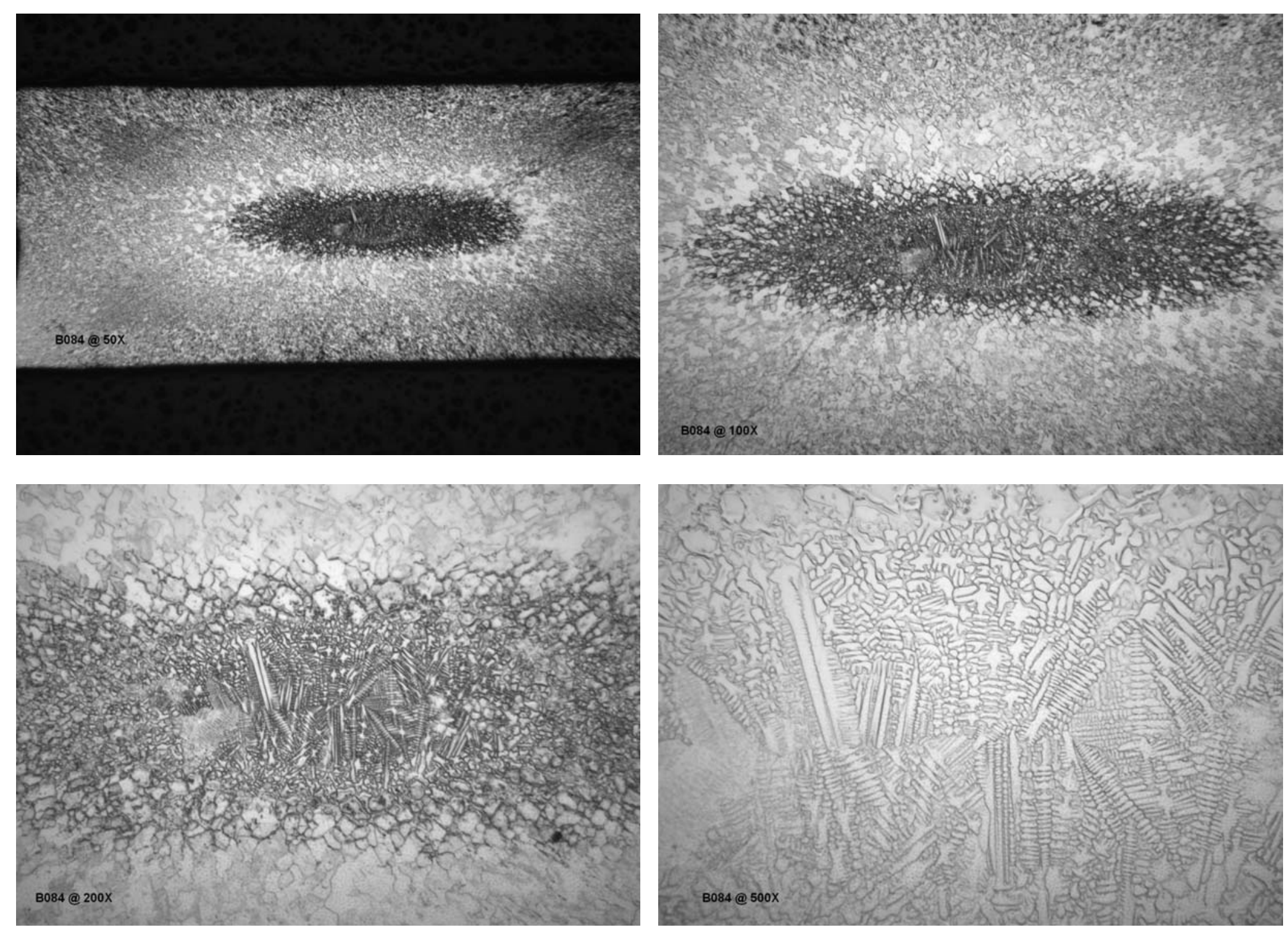

B084 Hot 
Appendix D. 21-6-9 pinch weld microstructure
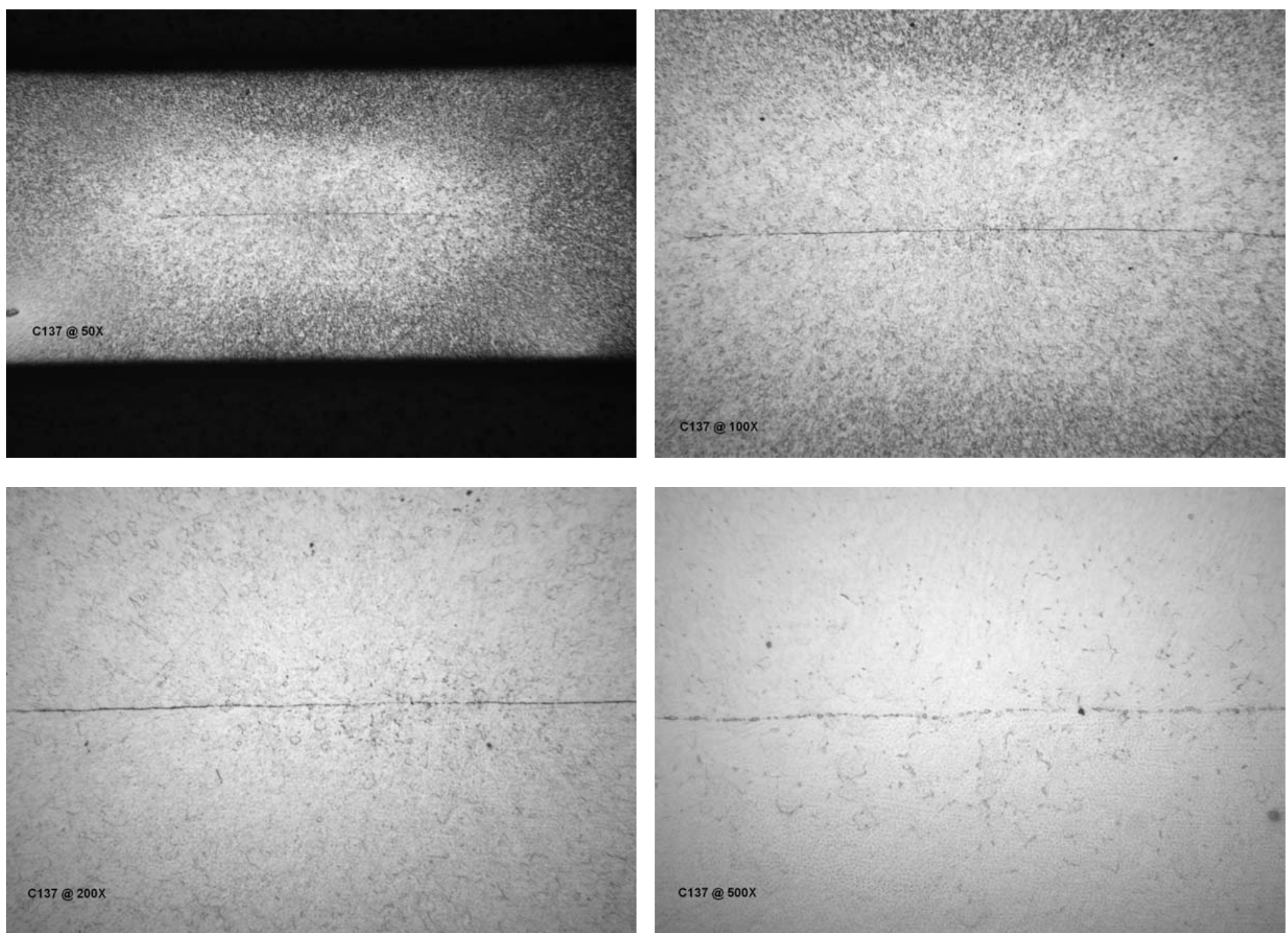

C137 Cold 

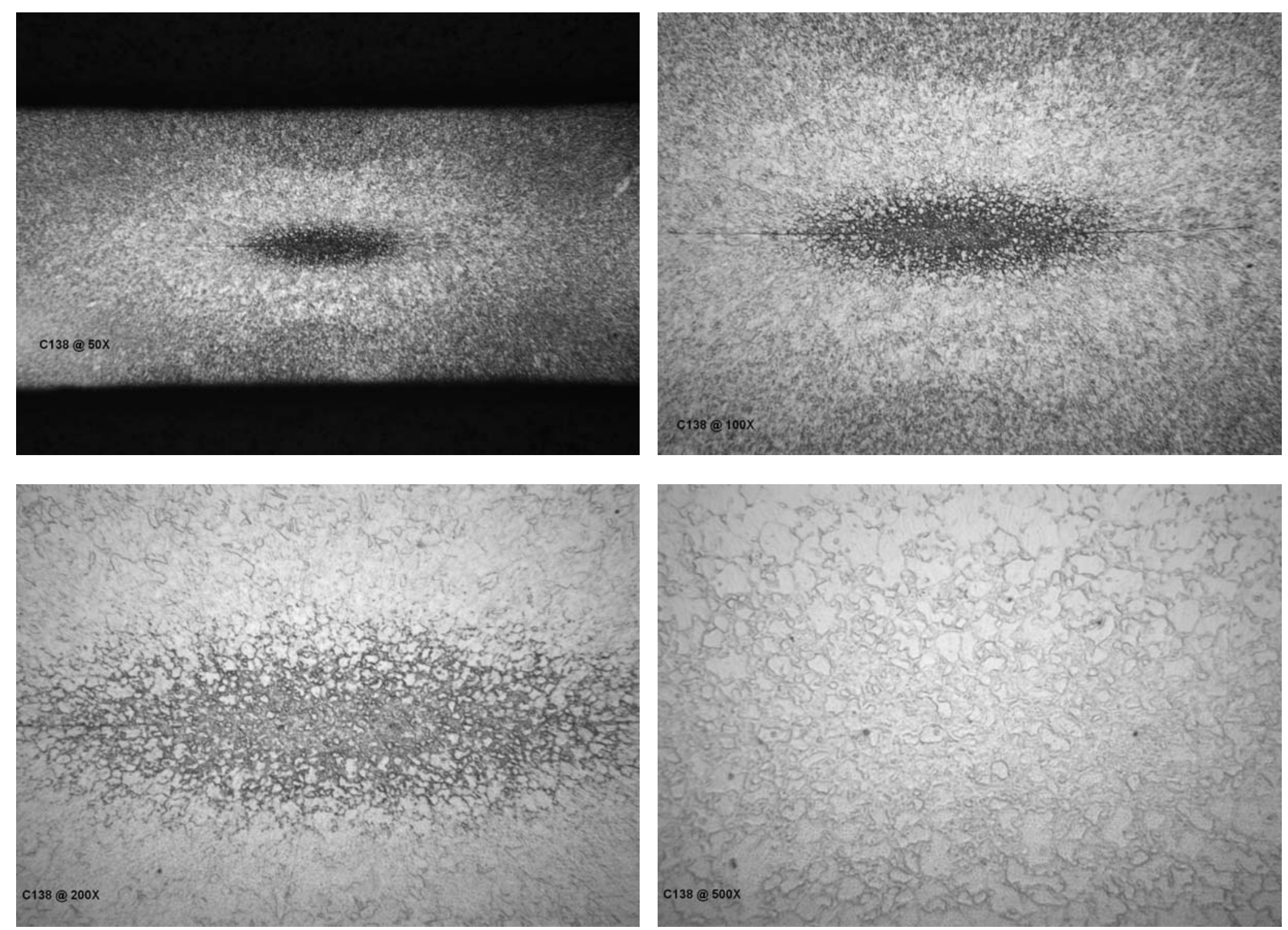

C138 Cold 

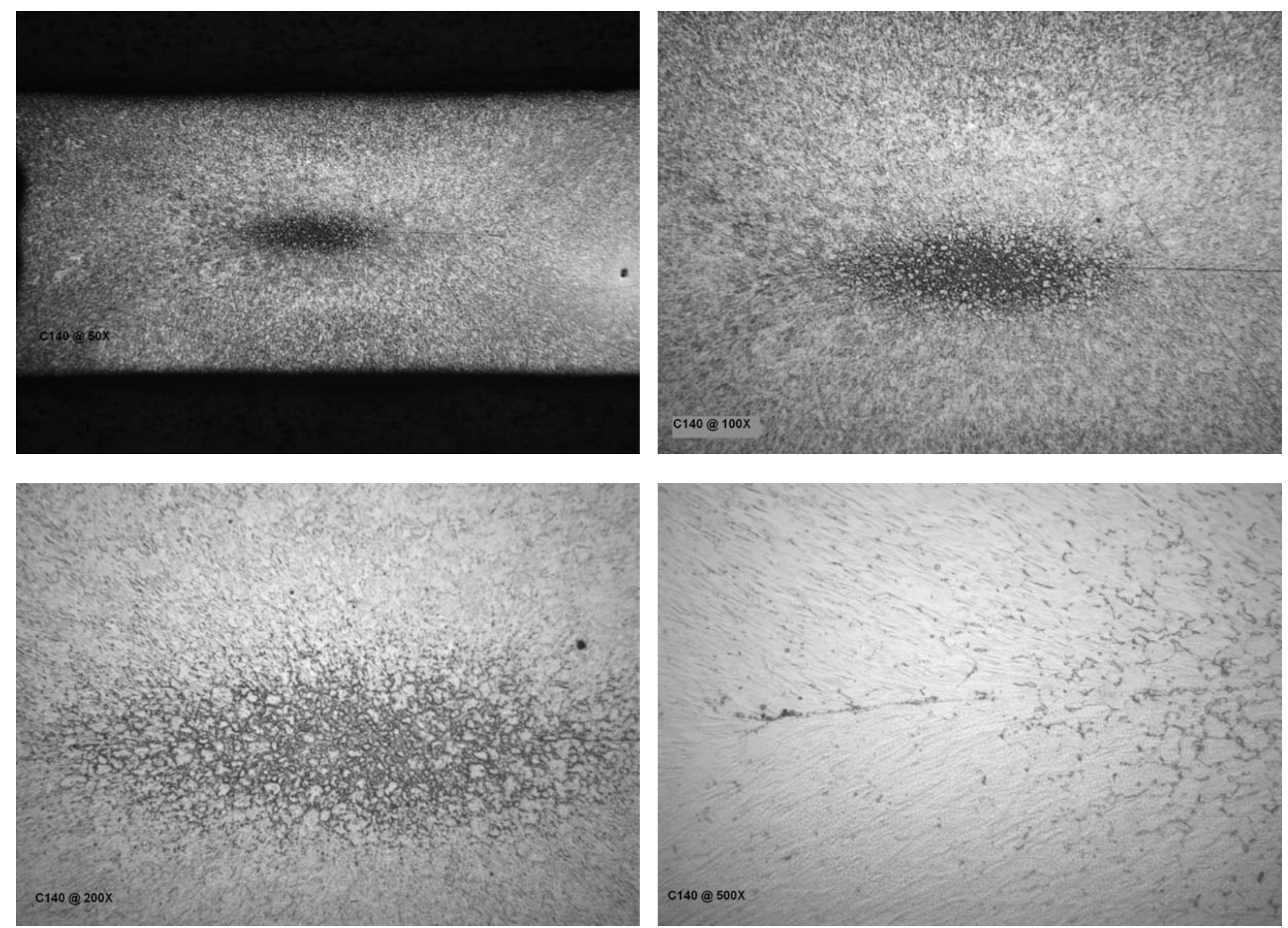

C140 Cold 

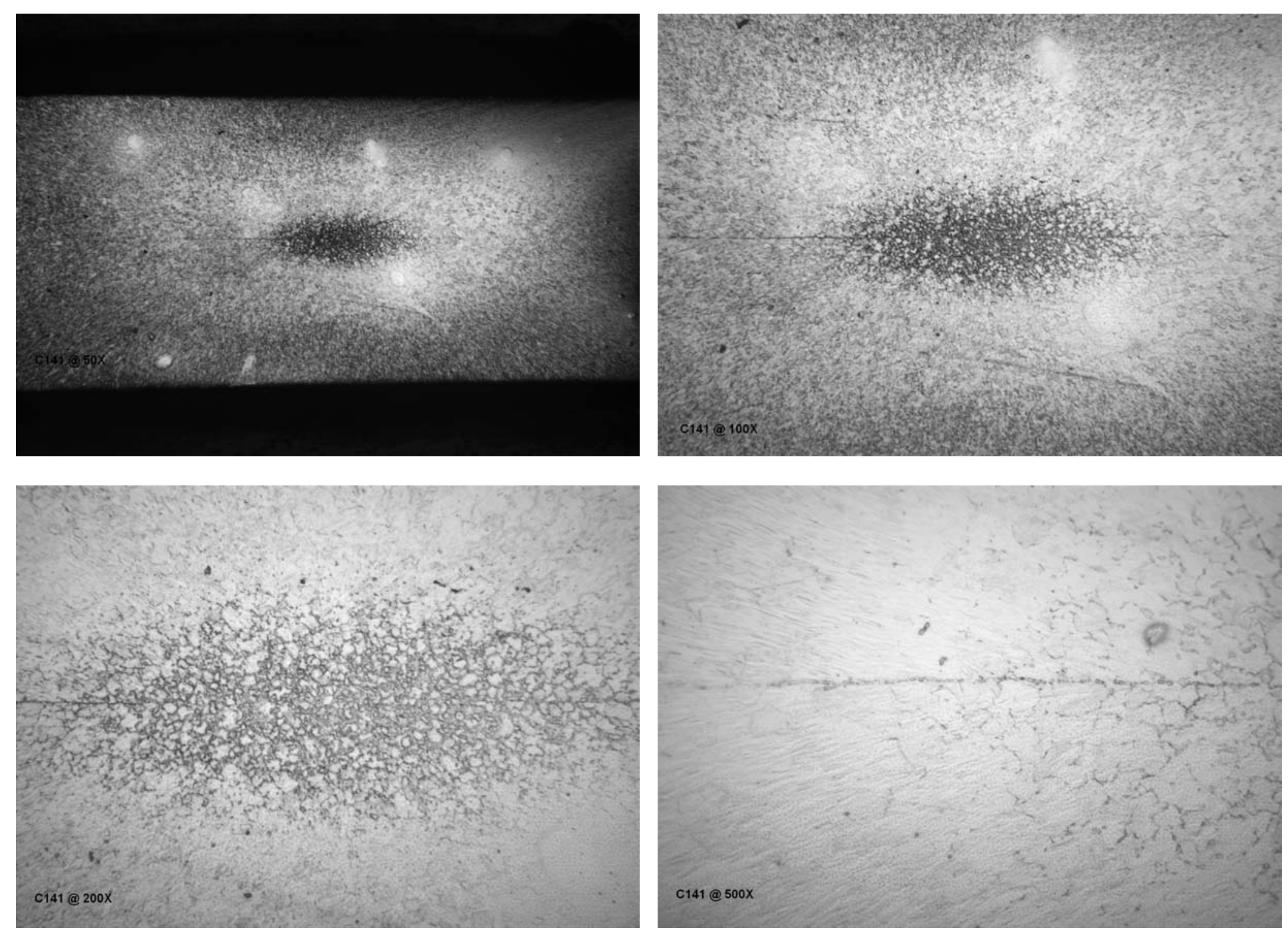

C141 Cold 

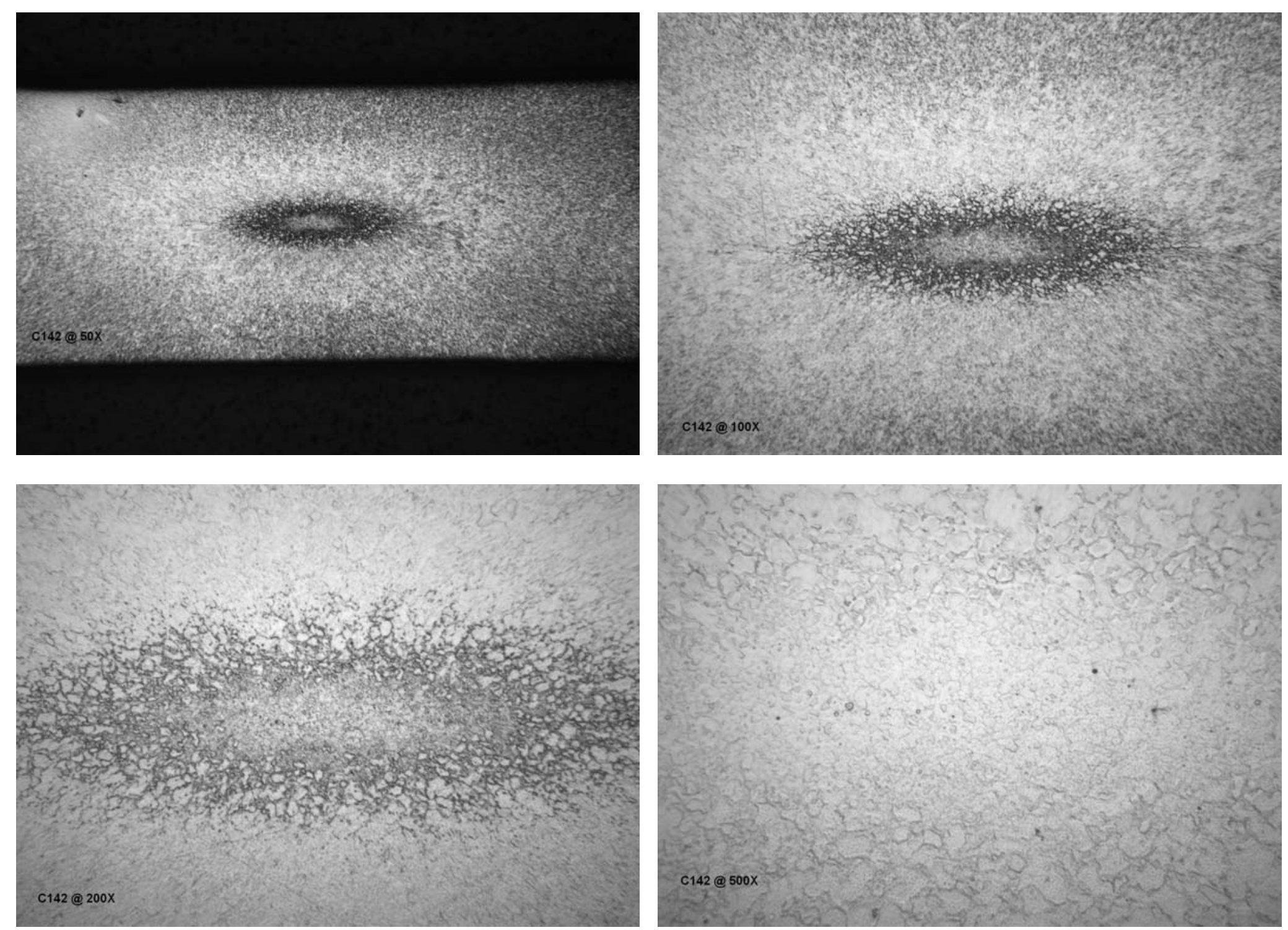

\section{C142 Nominal}



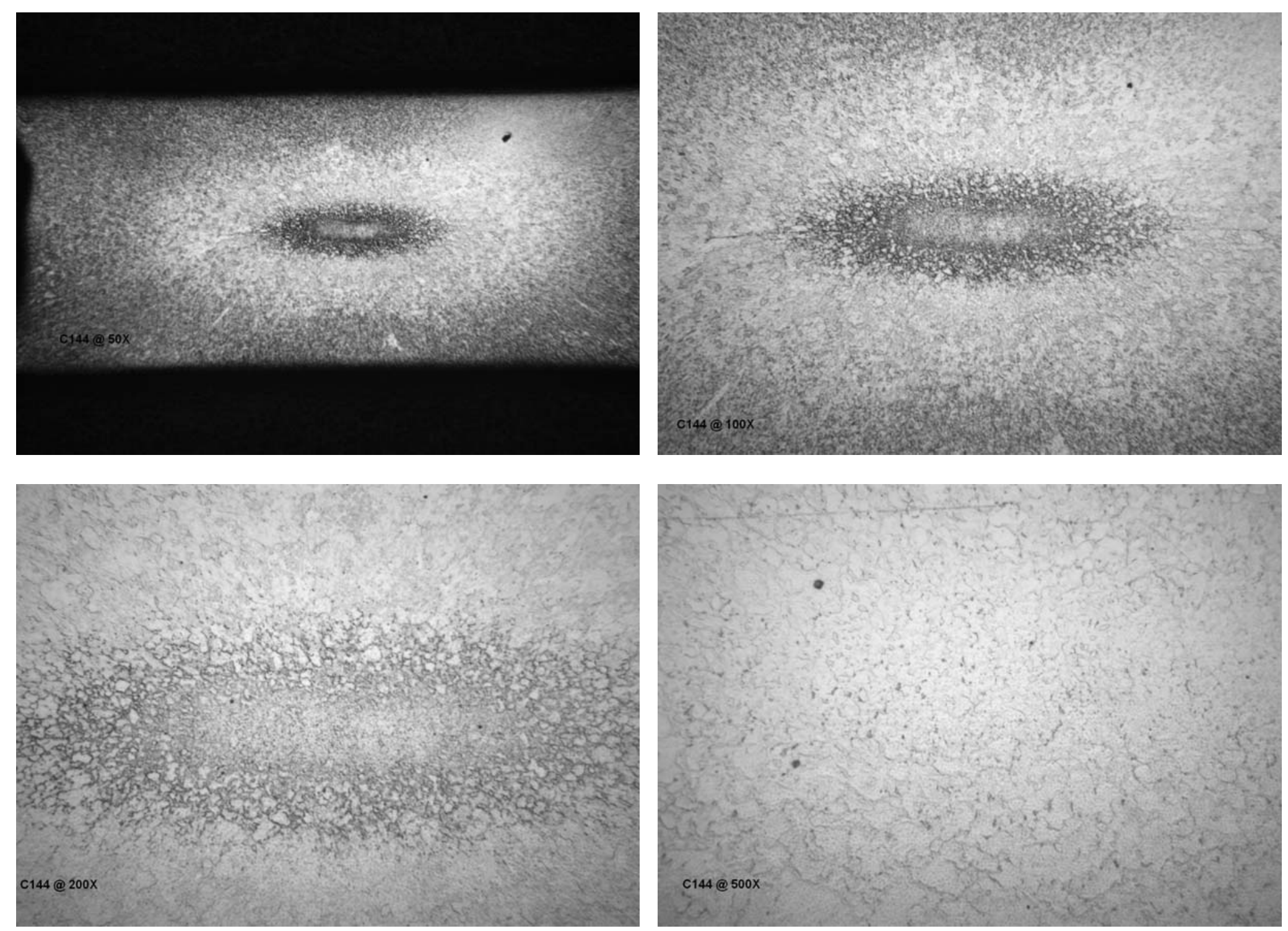

C144 Nominal 

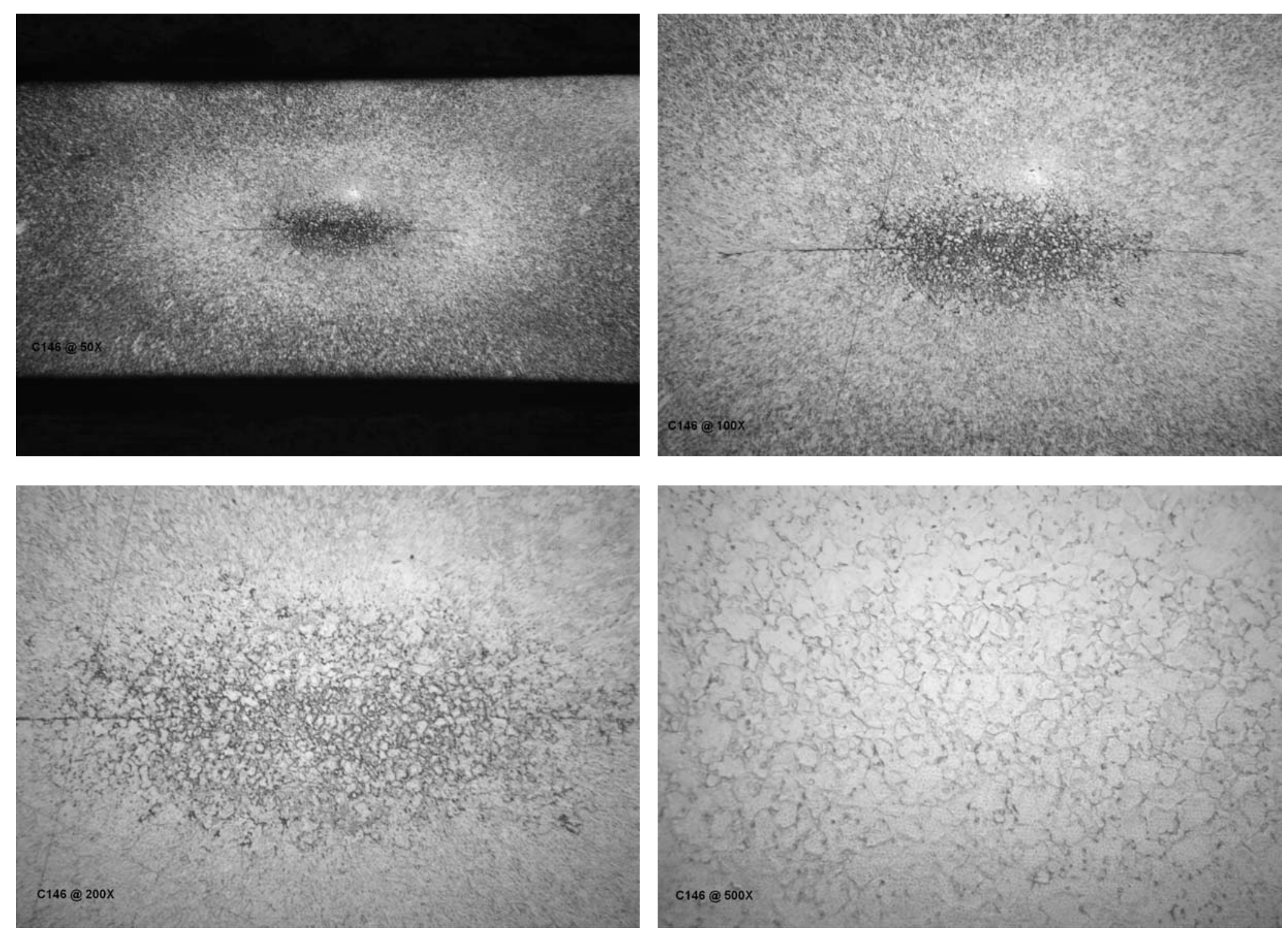

\section{C146 Nominal}



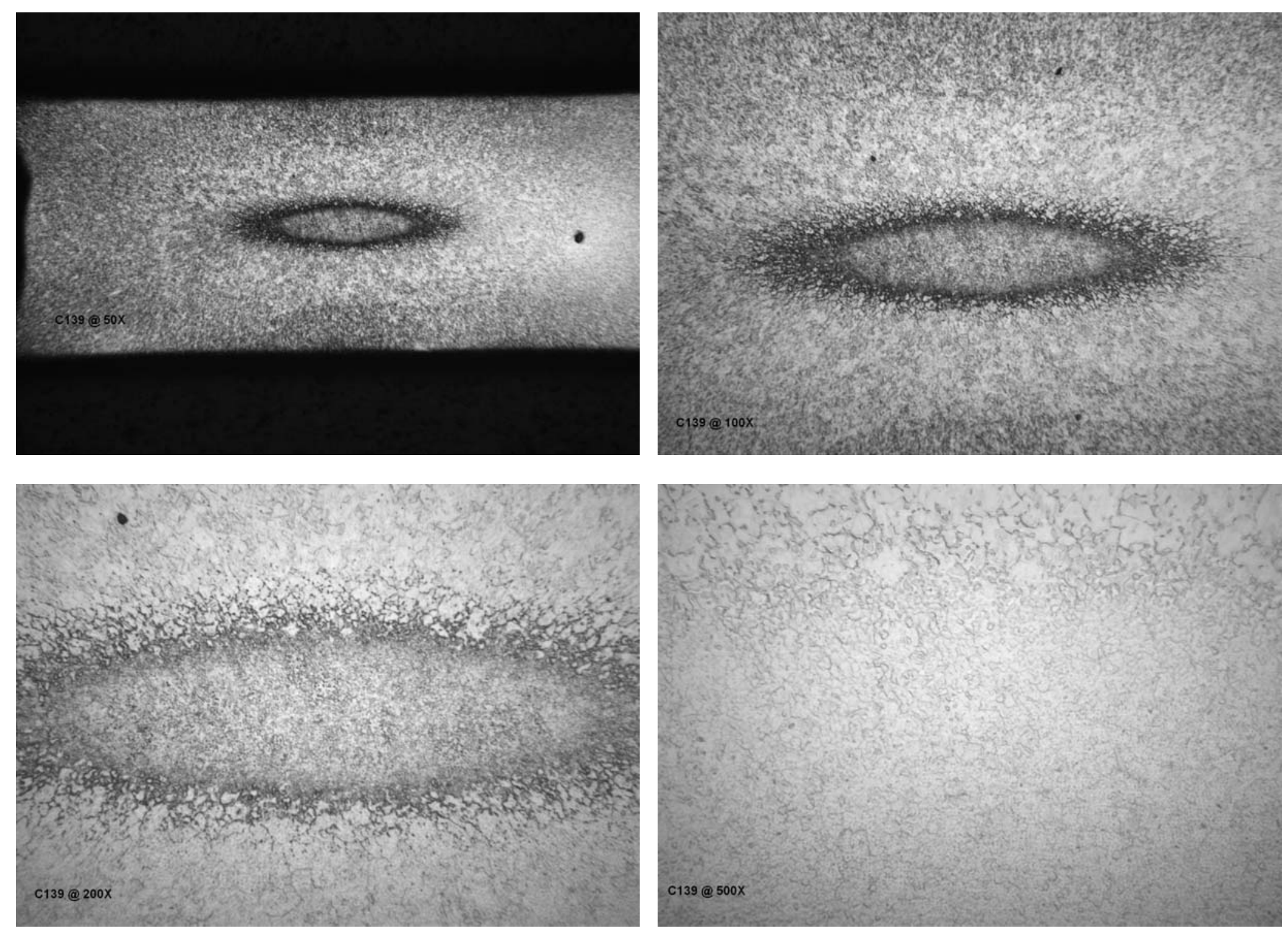

C139 Hot 

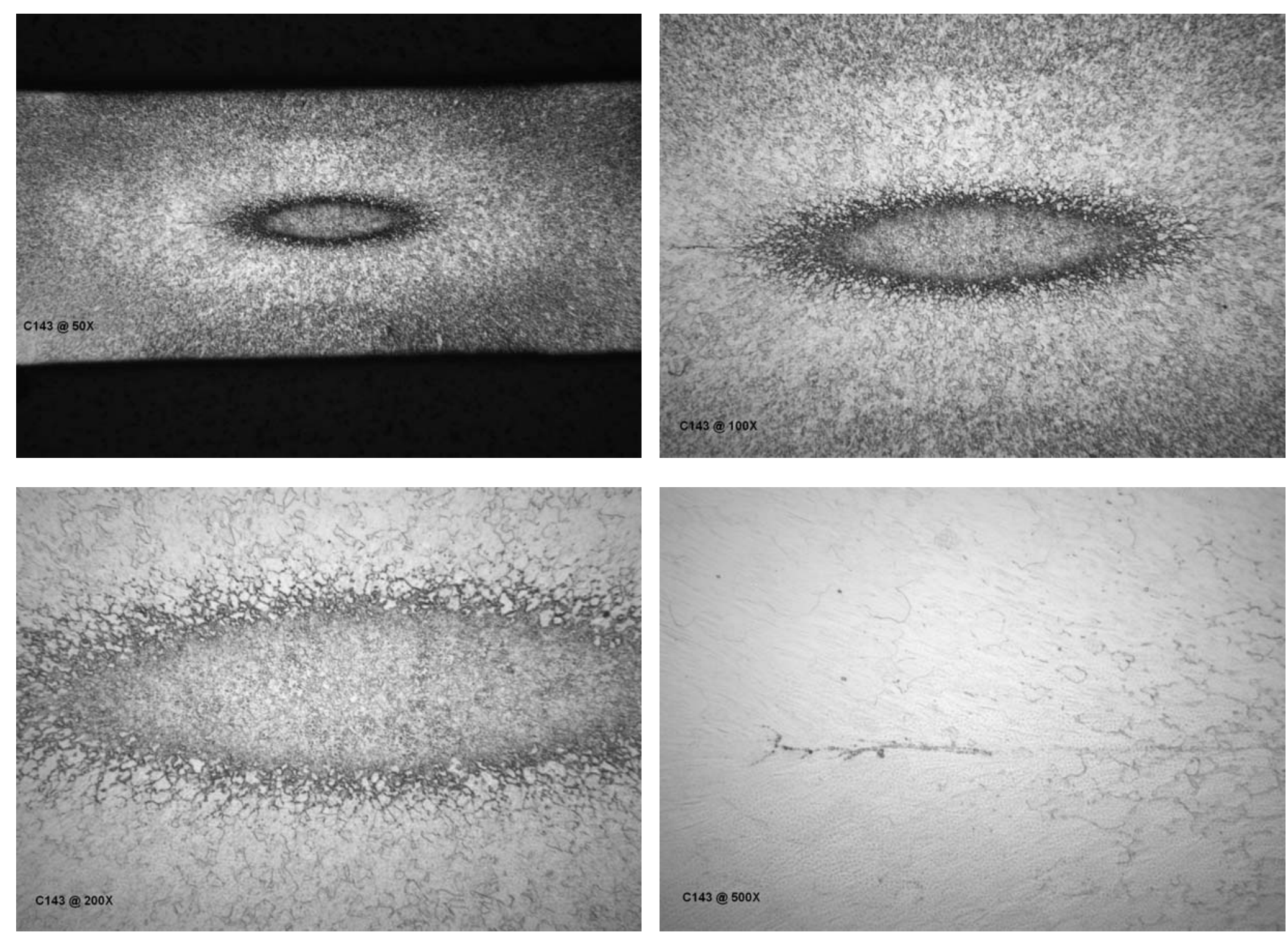

C143 Hot 

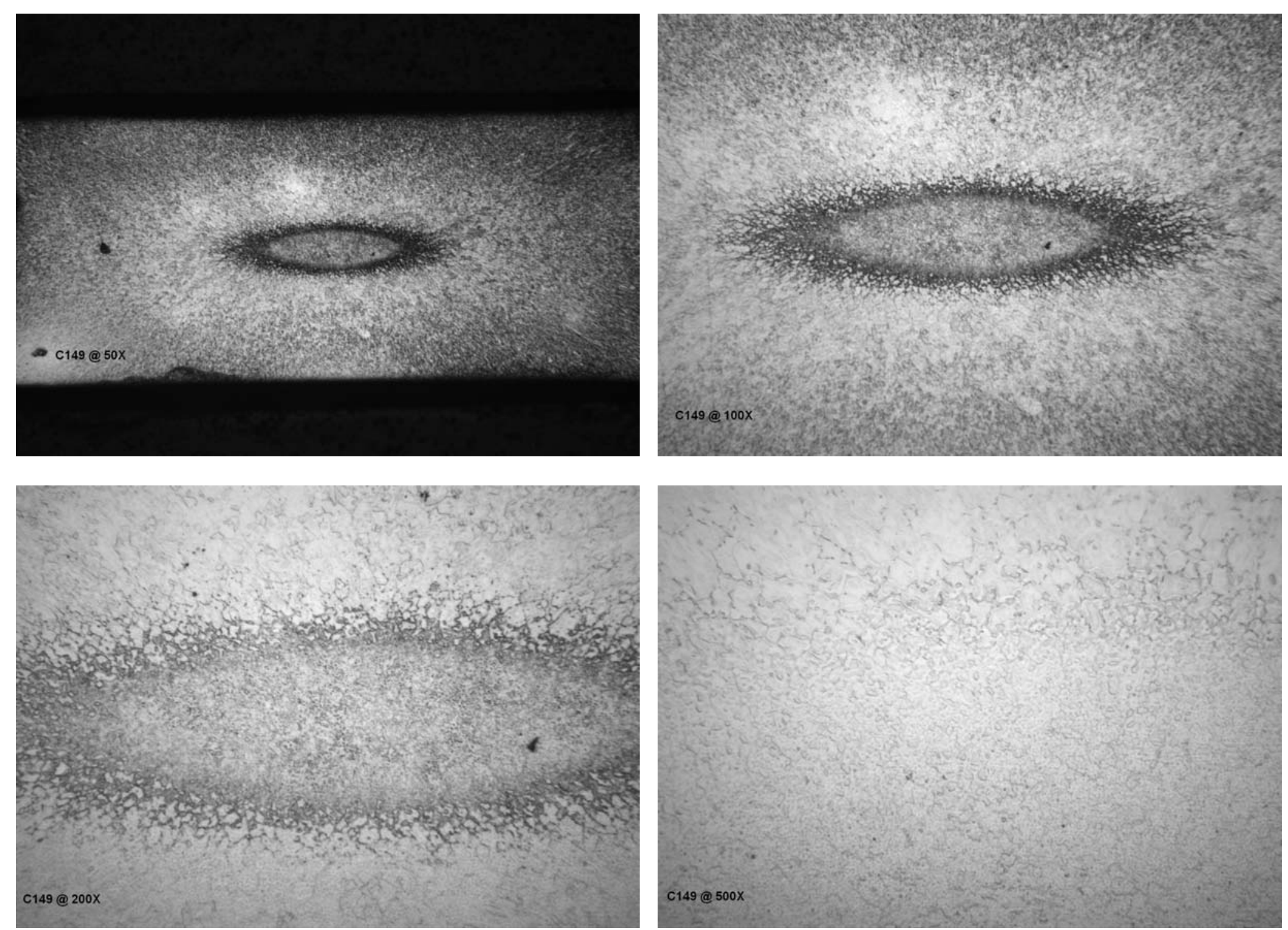

C149 Hot 